
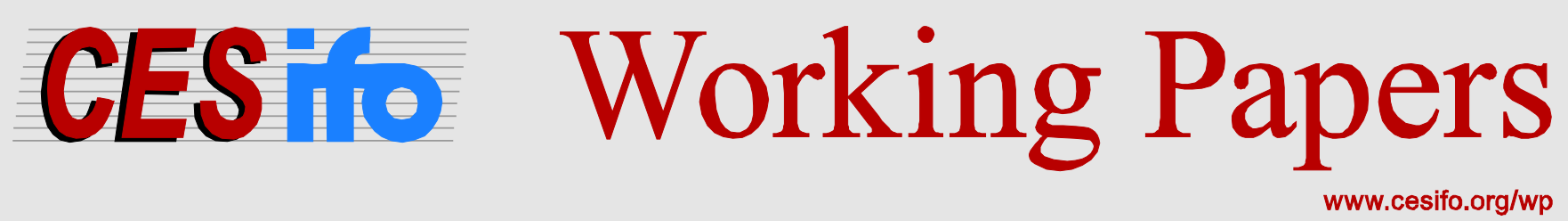

\title{
Policy and Politics: \\ Trade Adjustment Assistance in the Crossfire
}

\author{
Christopher Laincz \\ Xenia Matschke \\ Yoto V. Yotov
}

CESIFO WORKING PAPER NO. 5697

CATEGORY 8: TRADE POLICY

JANUARY 2016

An electronic version of the paper may be downloaded

- from the SSRN website:

- from the RePEc website:

- from the CESifo website:

wWw.SSRN.com

www.RePEc.org

www.CESifo-group.org/wp 


\title{
Policy and Politics: Trade Adjustment Assistance in the Crossfire
}

\begin{abstract}
The United States introduced Federal Trade Adjustment Assistance (TAA) as part of the 1962 Trade Expansion Act to dampen the adverse impact of increased trade on workers. Applications to receive TAA require approval from the Department of Labor. Guided by the technical criteria used by the U.S. government in the official TAA certification process, we capitalize on a rich multi-dimensional panel dataset to quantify the effects of political inuence on the TAA certification decision. We find that political factors such as party affiliation of the President, voting outcomes at the state level, and whether a petition was certified in an election year inuence the TAA certification outcome. Those effects remain even when including a wide array of controls and a rich set of fixed effects.
\end{abstract}

JEL-codes: F130, F140, F160.

Keywords: trade adjustment assistance, political economy, trade protection.

\author{
Christopher Laincz \\ School of Economics \\ LeBow College of Business \\ Drexel University \\ USA - Philadelphia, PA 19104 \\ cal38@drexel.edu
}

\author{
Xenia Matschke \\ Department of Economics \\ University of Trier \\ Germany - 54296 Trier \\ matschke@uni-trier.de
}

\author{
Yoto V. Yotov \\ School of Economics \\ LeBow College of Business \\ Drexel University \\ USA - Philadelphia, PA 19104 \\ yotov@drexel.edu
}

December 26, 2015

We thank Adeliada Mehmetaj for assistance in collecting data and participants of the CESifoWorkshop on Political Economy 2014 in Dresden (Germany) for valuable comments. 


\section{InTRODUCTION}

The United States introduced Federal Trade Adjustment Assistance (TAA) as part of the Trade Expansion Act of 1962 to dampen the adverse impact of increased trade on workers. From 1962 onwards, the U.S. combined extension of the TAA program with measures to facilitate and foster trade liberalization (see Hornbeck (2013) for a current overview of the history of TAA and its role in U.S. trade policy). While researchers question the actual benefits to workers of this program relative to regular unemployment insurance (Marcal, 2001; Baicker and Rehavi, 2004; Palatucci and Reynolds, 2012), TAA remains integral to obtaining Democrat support, in particular, for further liberalizing U.S. trade policy (Hornbeck, 2013).

We study the interplay between political influence and trade policy outcomes. Our results show considerable and significant effects even when including a wide array of controls and a rich set of fixed effects. Several main findings stand out. First, we find that, ceteris paribus, TAA petitions from Republican voting states are more likely to be certified. Second, our results suggest that Republican administrations are less likely to grant TAA. Third, we find that the certification probability increases in Presidential election years, suggesting that politicians are more sensitive to voter needs when elections are close. We use our results to draw quantitative inference about the relationship between voting outcomes (mainly at the state level, but also for Congress), Presidency, and TAA certification outcomes. For example, if a state votes Democrat and the Presidency switches from Democrat to Republican, the probability of certification falls by approximately $10 \%$.

Our analysis capitalizes on the institutional design of the TAA certification process in combination with a detailed multi-dimensional database that covers all TAA petitions and the corresponding government decisions over the period 1980-2005. To obtain TAA, a firm needs to be certified by the TAA administration under the Department of Labor (DoL), which, in turn, requires a group of at least three workers, the workers' employer, 
a union official, or a Job Center operator to petition for certification. Once a firm is certified for TAA, the firm's workers whose jobs were lost due to trade-related circumstances can apply for assistance such as job retraining and prolonged unemployment benefits. For our analysis, we compile a novel data set that covers relevant variables of TAA certification at the state and at the 4-digit SIC (Standard Industry Classification) 1972 sectoral level for manufacturing in the United States over the period 1980-2005.

Our dependent variable is the outcome of the certification process, i.e., whether or not a TAA petition was approved. It varies by state, industry, and over time and it is obtained from the Petition for Trade Adjustment Assistance (PTAA) Database, constructed and maintained by the Employment and Training Administration of the U.S. DoL. The PTAA consists of firm-level data including the 4-digit SIC industry, the state of the filing firm or plant, the date when the petition for TAA is filed, the initiator of the petition, when and whether the petition is certified by the DoL, and the estimated number of workers to be laid off by each firm or plant as a consequence of the increase in imports or shifts in production outside the United States. Throughout our analysis, we use logistic regressions (logit) to predict the probability of certification as a linear function of our explanatory variables.

Guided by the main technical criteria used by the U.S. government in the official TAA certification process and by related contributions in the academic literature, e.g. Magee (1997) and Magee (2001), we control for a series of factors such as the level and the change in industry exports and imports, the level and change in industry tariffs, state unemployment and unionization rates, number of establishments, etc. We also experiment with a rich set of fixed effects to control for various characteristics across the three dimensions of our data (state, industry, and time) that may affect the government's decision to certify a TAA petition. Finally, we dig deeper into the political influence on TAA certification by introducing additional political variables pertaining to the composition of Congress (Senate and House of Representatives) and state governors' party 
affiliations. Our main findings remain robust to a series of alternative specifications and sensitivity experiments.

Our work is closely related to several existing papers by Christopher Magee, and to two broader strands of the literature. The Magee (1997) and Magee (2001) papers, like us, study the determinants of TAA certification outcomes. Our contribution in relation to Magee's work is that we introduce and focus our analysis on a new set of political determinants of TAA certification outcomes. In addition to finding strong support for the importance of politics and political influences, we complement Magee's findings by offering stronger support for some of his hypotheses, but weaker evidence for others. For example, we obtain positive and significant estimates of the effects of tariffs and their changes on TAA certification. The finding with respect to the effect of the level of protection/tariffs is exactly in accordance with the intuition from Magee (1997) and Magee (2001), which predict that the DoL should be more likely to certify workers the higher the tariff in their industry. However, the positive and significant estimate that we obtain for the effect of tariff changes does not support the intuitive argument that "trade adjustment assistance can be used as a payment to labor groups in order to lessen the harm done when tariff cuts lead to increased imports" (Magee, 2001, p.113). Magee (2001) himself finds only tentative support for this hypothesis. Our interpretation of the strictly positive and highly statistically significant estimate of the effects of tariff changes is that the U.S. government uses a mix of tariff protection and TAA measures to dampen the impact of adverse economic conditions.

Our paper also naturally belongs to the political economy literature. Economists have long come to the conclusion that the TAA program has serious flaws and deficiencies and that its benefits, compared to the considerable costs, are rather limited and only available to a small group of workers (Marcal, 2001; Baicker and Rehavi, 2004; Palatucci and Reynolds, 2012), namely those laid off due to adverse trade effects. For 
this reason, domestic welfare maximization is not an obvious explanation for the existence and continuation of TAA, whereas the political economy literature offers a broad range of rationales why politicians choose policies that are suboptimal from the standpoint of a benevolent planner. One way of explaining TAA would be via a protection for sale lobbying model (Grossman and Helpman, 1994) that leads to a policy outcome similar to one where lobby group welfare receives a large weight in a political support function, thus providing a micro foundation for this approach. ${ }^{1}$ The influence of worker lobbying and unemployment can be easily incorporated into this framework as shown in Matschke and Sherlund (2006) and Matschke (2010). However, the protection for sale literature focuses on explaining trade protection and assumes a financial linkage between lobby groups and politicians: lobbies pay politicians to induce a certain (trade) policy outcome. For this reason, empirical tests of the model typically rely on campaign contributions to determine whether a population group actively lobbies (e.g. Goldberg and Maggi (1999), Gawande and Bandyopadhyay (2000)). For the TAA certification process, we do not have any indication that it is influenced by financial payments. In our work, we use a vote function approach instead to motivate the TAA certification choice, which seems reasonable given that we demonstrate that voting outcomes at the national and state level have a non-negligible impact on TAA certification.

By capitalizing on the richness and uniqueness of the TAA database, our work is also related to a small series of papers that similarly employ this, in our view still underutilized, data source. In addition to Magee (1997) and Magee (2001), which we already discussed earlier, we refer the interested reader to Yotov (2010) and Yotov (2013) which use the TAA database to construct trade-induced unemployment variables that appear as additional determinants of protection in the PfS framework. Also relevant is Kondo (2013) which employs the TAA data to investigate the effects of trade on labor

\footnotetext{
${ }^{1}$ Dutt and Mitra (2005) show in an empirical model motivated by the political support function approach that right and left governments choose different trade policies, presumably because of differing welfare weights for different population groups.
} 
market outcomes across locations, and Uysal, Yotov, and Zylkin (2015) which studies the determinants of trade-induced layoffs in a setting with heterogeneous firms a la Melitz (2003).

The remainder of the paper is organized as follows. In Section 2, we present a simple theoretical model which describes the choice of whether or not to grant trade adjustment assistance as the government's maximization of the expected number of votes which in turn depends on the costs and benefits (in particular the reemployment of workers) of TAA. Guided by our theory, in Section 3, we specify an econometric model of the probability of TAA certification as a function of political variables, trade and other control variables, a trend variable and regional and industry fixed effects. Section 4 offers a description of our data and sources. Section 5 provides a preliminary look at the relationship between TAA certification and our political variables. Section 6 presents our main results and offers a series of alternative specifications and robustness experiments. Section 7 concludes.

\section{THEORY}

Consider an environment where consumers maximize a quasilinear utility function. Good A is the numeraire good, and its price is normalized to 1. Consumption of good B enters utility non-linearly and its price is denoted by $p$. The indirect utility or welfare function which is dual to the direct utility function then consists of consumer income plus the consumer surplus from consuming good B.

The numeraire sector $A$ uses a one-to-one production technology which transforms one unit of labor into one unit of output. For both sectors to coexist, it must then be the case that the wage rate is equal to 1 , i.e., the price of good $A$. Production in industry $B$ uses both capital $K_{B}$ and labor $L_{B}$, where $K_{B}$ is fixed and equal to the number of capital

owners. The total number of workers equals $\bar{L}$. Without loss of generality, we think of good $B$ as an import good. Workers need special training in order to be qualified to 
work either in sector $A$ or sector $B$. If workers in one sector lose their jobs, they will need training to find employment in the other sector.

To discuss the choice of granting trade adjustment assistance (TAA) and motivate our empirical analysis, we use a simple two-period model where $t=1,2$. In the preceding period 0, we assume full employment, whereas from period 1 onwards, an exogenous price drop of good $B$ (either because the world market price fell or because of a reduction in the import tariff rate) creates unemployment. Period 2 unemployment can be reduced by granting unemployed workers trade adjustment assistance in period 1 such that they may find work in sector $A$ in period 2. We denote the fraction of unemployed workers receiving TAA by $\theta$. TAA in our model is financed by lump-sum taxes on employed workers and capital owners and consists of two components: training assistance $t_{T A A}$ helps unemployed sector $B$ workers qualify for sector $A$ jobs in period 2 and can thus be called an investment; the second component, namely additional unemployment assistance $u_{T A A}$ paid in period 1 , is a purely redistributive measure. We model the reemployment function $g($.$) as an increasing and strictly concave function of the number$ of unemployed workers receiving training. We assume $0<g^{\prime}<1$ such that an increase in $\theta$ increases the number of employed workers in period 2, but the increase in workers receiving TAA is always higher than the increase in workers finding reemployment in period 2. The share $\theta$ of unemployed workers receiving TAA is chosen optimally by the government to maximize the number of expected votes. We assume an interior solution for this optimal $\theta$, i.e. $\theta \in(0,1)$. Whereas an increase in $\theta$ improves welfare for the unemployed workers receiving trade adjustment assistance, capital owners and employed workers have to bear the cost for retraining and unemployment benefits via lump-sum taxes, and their welfare is consequently reduced.

We define welfare for several different population groups. We denote capital owner per-capita welfare as $W_{K}$. The number of capital owners, $K_{B}$, is unaffected by $\theta$, changes 
in the percentage of unemployed workers receiving TAA. However, capital owner welfare is negatively affected by $\theta$ because they pay a share of the TAA cost.

In addition, the population consists of four different worker groups: those who are always employed, those who are always unemployed and do not receive TAA, those who are always unemployed and receive TAA, and those who are unemployed in period 1 and employed in period 2 thanks to the retraining received via TAA. We denote the number of workers who are always employed by $L_{e e}$ and their per-capita welfare by $W_{e e}$. The number of workers who become unemployed in period 1 equals $\bar{L}-L_{e e}=\Delta L_{B} \geq 0$, showing that these workers have been set free by the contraction in sector $B .^{2}$ This latter group can be further subdivided into groups. There are $(1-\theta) \Delta L_{B}$ workers who are unemployed in both periods and did not receive TAA. An increase in $\theta$ reduces the number of workers in this group. Group per-capita welfare $W_{u u}^{n o t T A A}$ is not affected by TAA since these workers neither receive TAA benefits nor pay for them. Then there are $g\left(\theta \Delta L_{B}\right)$ workers who receive TAA benefits in period 1 and find a job in period 2 . This population is increasing in $\theta$. Per-capita welfare $W_{u e}^{T A A}$ for this worker group includes additional unemployment benefits $u_{T A A}$ in period 1 and a wage of 1 in period 2. Finally, $\theta \Delta L_{B}-g\left(\theta \Delta L_{B}\right)$ workers receive TAA benefits in period 1 , but are still unable to find employment in period 2. Given that we assumed $g^{\prime}<1$, the number of these workers also rises with $\theta$. Their per-capita welfare $W_{u u}^{T A A}$ includes the additional unemployment benefit $u_{T A A}$ in period 1 .

We now introduce an expected vote function $V$ which assigns a probability of an individual's voting for the government to each individual welfare level and which is strictly increasing and concave in its argument. The shape of the voting function also depends on whether the individual is a capital owner or a worker $\left(V_{K}\right.$ or $\left.V_{L}\right)$ and furthermore on

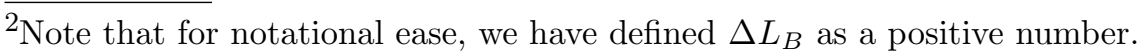


the government party and other factors. The government chooses $\theta$ to maximize $V$ :

$$
\begin{aligned}
V=K_{B} V_{K}\left(W_{K}(\theta)\right)+ & L_{e e} V_{L}\left(W_{e e}(\theta)\right)+(1-\theta) \Delta L_{B} V_{L}\left(W_{u u}^{n o t T A A}\right) \\
& +g\left(\theta \Delta L_{B}\right) V_{L}\left(W_{u e}^{T A A}\right)+\left[\theta \Delta L_{B}-g\left(\theta \Delta L_{B}\right)\right] V_{L}\left(W_{u u}^{T A A}\right)
\end{aligned}
$$

which gives the number of votes expected for the government party as a function of the share $\theta$ of unemployed workers receiving TAA. Assuming an interior solution, the first-order condition is

$$
\begin{aligned}
\overbrace{K_{B} V_{K}^{\prime}\left(W_{K}\right) \frac{d W_{K}}{d \theta}}^{-}+\overbrace{L_{e e} V_{L}^{\prime}\left(W_{e e}\right) \frac{d W_{e e}}{d \theta}+\overbrace{\left[-\Delta L_{B} V_{L}\left(W_{u u}^{n o t T A A}\right)\right]}^{-}}^{-} & \overbrace{\overbrace{\Delta L_{B} g^{\prime} V_{L}\left(W_{u e}^{T A A}\right)}^{T A A}}^{+}+\overbrace{\Delta L_{B}\left(1-g^{\prime}\right) V_{L}\left(W_{u u}^{T A A}\right)}^{T A}=0
\end{aligned}
$$

with $\frac{d W_{K}}{d \theta}=\frac{d W_{e e}}{d \theta}=-\frac{\left(u_{T A A}+t_{T A A}\right) \Delta L_{B}}{K_{B}+\text { Lee }}$. The first two terms show the decrease in votes by capital owners and always employed workers who pay more taxes for TAA. Term 3 shows the decrease in votes coming from unemployed workers who do not receive TAA since their number falls with increased $\theta$ although their welfare is unaffected. Similarly, terms 4 and 5 show the vote increase coming from workers who receive TAA since their number increases. In sum, the number of votes from workers unemployed in period 1 increases with $\theta$ since $W_{u e}^{T A A}>W_{u u}^{T A A}>W_{u u}^{n o t T A A}$ while the number of votes from capital owners and those always employed declines in $\theta .^{3}$

From (2.2), the optimal share of unemployed workers who will be granted TAA depends on many factors from the government's point of view. Among them are the number of laid-off workers, the number of persons in the different groups, and the shapes of the expected vote functions for the different population categories. ${ }^{4}$ For example, the

\footnotetext{
${ }^{3}$ The second-order condition for a maximum holds given the strict concavity of $g, V_{L}$, and $V_{K}$. ${ }^{4}$ It also seems reasonable to assume that the expected vote functions differ by group. In the simple model, we assume differences between workers and capital owners, but the vote functions may also depend on regional differences in voting behavior, for example.
} 
sign of the impact of the number of laid-off workers on optimal $\theta$ equals the sign of the derivative of $(2.2)$ with respect to $\Delta L_{B}$ :

$$
\begin{gathered}
\overbrace{\left[K_{B} V_{K}^{\prime \prime}\left(W_{K}\right)+L_{e e} V_{L}^{\prime \prime}\left(W_{e e}\right)\right]\left(\frac{\left(u_{T A A}+t_{T A A}\right)^{2} \theta \Delta L_{B}}{\left(K_{B}+L_{e e}\right)^{2}}-\left[K_{B} V_{K}^{\prime}\left(W_{K}\right)+L_{e e} V_{L}^{\prime}\left(W_{e e}\right)\right] \frac{u_{T A A}+t_{T A A}}{K_{B}+L_{e e}}\right.}^{-} \\
+\overbrace{\Delta L_{B} \theta g^{\prime \prime}\left[V_{L}\left(W_{u e}^{T A A}\right)-V_{L}\left(W_{u u}^{T A A}\right)\right]}^{+} \\
+\overbrace{g^{\prime}\left[V_{L}\left(W_{u e}^{T A A}\right)-V_{L}\left(W_{u u}^{T A A}\right)\right]}^{+}+\overbrace{V_{L}\left(W_{u u}^{T A A}\right)-V_{L}\left(W_{u u}^{\text {not TAA }}\right)}^{+}
\end{gathered}
$$

The term under the first brace is negative, showing that the marginal vote of employed workers and capital owners is further reduced by an increase in unemployment. The

second term is also negative reflecting diminishing returns to the reemployment function. The third and fourth terms reflect the positive effect of the increased number of unemployed who benefit from TAA. Not surprisingly, the sign of this expression is indeterminate due to conflicting effects on the marginal votes. In what follows, we investigate empirically the political determinants of the certification share/probability $\theta$.

\section{ECONOMETRiC Specification}

In this section, we specify an econometric model that captures the effects of political influence on the certification rate $\theta$, which can also be interpreted as certification probability. As possible determinants of $\theta$, we include variables that measure whether the state in which the workers seek certification voted Democrat or Republican during the last Presidential election, whether the President is Republican or Democrat, an interaction term between the state and the President variable and also whether the year in question was an election year. Specifically, our estimating equation takes the following 
form:

$$
\begin{aligned}
\operatorname{CERTIFIED} D_{c, s, i, y}= & \beta_{0}+\beta_{1} R E P P R E S_{y}+\beta_{2} R E P S T A T E_{s, y}+\beta_{3} R E P P R E S_{y} * R E P S T A T E_{s, y} \\
& +\beta_{4} E L Y E A R \_P R E S_{y}+\beta_{5} Y E A R_{y}+\beta_{6} E S T \_W R K R S_{c, s, i, y} \\
& +\alpha^{\prime} X_{s, i, y}+\gamma^{\prime} Y_{s, y}+\delta^{\prime} Z_{i, y}+\phi_{s}+\phi_{i}+\varepsilon_{c, s, i, y}
\end{aligned}
$$

Here, CERTIFIE $D_{c, s, i, y}$ is an indicator variable that takes a value of one if a TAA petition case $c$ coming from state $s$ in industry $i$ is certified (or partially certified) in year $y$. Given the dichotomous nature of our dependent variable, throughout our analysis we use logistic regressions (logit) to predict the probability of certification as a linear function of our explanatory variables.

The main covariates in (3.1) capture how the interactions between political support at the state level and the outcomes of the Presidential elections in the U.S. affect the probability of TAA certification. REPPRES is an indicator variable that takes a value of 1 if the President in power is from the Republican party, and REPSTATE $E_{s, y}$ equals 1 if a state voted Republican in the last Presidential election and zero otherwise. Using this set of dummy variables, we can capture differences in certification probabilities based not only on the state voting behavior or the party affiliation of the President in power, but also based on their interaction. The indicator variable ELYEAR_PRES takes a value of 1 in an election year and 0 otherwise. In addition, we include a time trend $Y E A R_{y}$ and the estimated number of workers $E S T_{-} W R K R S_{c, s, i, y}$ that will be laid off due to import competition, as stated in the TAA petition.

The above variables included in our specification capture, presumably, political motivations reflected in the executive branch's decision to grant TAA, i.e. its choice of $\theta$ in our model. Our hypothesis is that political variables, even after having controlled for other factors, should alter the probability of certification. Given the nature of our dependent variable, we do not believe that the relationship between our political variables and the probability for TAA certification is plagued by endogeneity due to simultaneity. 
It is not likely that the outcomes of the TAA certification process have any effects on the prior voting decisions at the state level. However, a wide variety of other factors could potentially affect $\theta$ including trade-related factors, employment and unemployment levels, and industry-level factors at the state level. Some of these factors may also affect voting decisions at the state level. Thus, our political influence estimates may be subject to bias due to omitted variables. In order to correct for that, we account for additional influences through a series of control variables and with a rich set of fixed effects.

Guided by the main technical criteria used by the U.S. government in the official TAA certification process and by related contributions in the academic literature, in particular Magee (1997) and Magee (2001), we also control for a series of factors that may affect the probability for TAA certification. In particular, $X_{s, i, y}$ in equation (3.1) is a vector of explanatory variables that vary across state, industry, and year. Here, we include covariates such as employment, payroll, number of establishments, etc. $Y_{s, y}$ is a vector of covariates in addition to the political variables that vary by state and year, such as unemployment and unionization rates, and $Z_{i, y}$ denotes a vector of explanatory variables that vary by industry and year, such as imports and exports, the change in imports and exports, tariffs and the change in tariffs. The latter are used by Magee (2001) to study the importance of equity and efficiency considerations in the DoL's decisions to certify workers for trade adjustment assistance. All the covariates are described in detail in Section 4. Finally, we also experiment with fixed effects for states $\left(\phi_{s}\right)$ and SIC-2 (1972) industry classifications $\left(\phi_{i}\right)$.

\section{Data And Sources}

In order to conduct the analysis in our study, we compiled a novel database that covers the relevant variables at the state and at the 4-digit SIC (1972) sectoral level for manufacturing in the United States over the period 1980-2005. We concentrate on manufacturing for several reasons. First, the manufacturing sectors in the U.S. are typically 
the ones most affected by import competition. Second, manufacturing is a large driver of the U.S. economy. Third, three quarters (75.6 percent) of the petitions in the Petition for Trade Adjustment Assistance (PTAA) database came from manufacturing sectors. In fact, until the American Recovery and Reinvestment Act of 2009, service workers as the largest employment group were not eligible for TAA assistance, see Hornbeck (2013). Finally, the most complete and reliable data for many of the sectoral-level control variables (e.g. production data, data on exports, imports, and tariffs) are available almost exclusively for manufacturing.

Our dependent variable $C E R T I F I E D_{c, s, i, y}$ is obtained from the PTAA Database. This data set is constructed and maintained by the Employment and Training Administration of the U.S. DoL. The PTAA data contain information on all TAA petitions filed during the period 1980-2005, which determines the time span of our investigation. More specifically, the PTAA consists of firm-level data including the following key variables: (i) the 4-digit SIC 1972 industry to which the firm filing for TAA belongs. This variable enables us to merge the TAA data with our control variables at the industry level; (ii) the state of the filing firm. This variable allows us to add control covariates at the state level. It is important to emphasize that the state of a filing firm is the state where the company or its branch resides physically. Thus, subsidiaries of the same company, which operate in different states, file separate TAA petitions; (iii) the date when the petition for TAA is filed; (iv) the initiator of the petition $;^{5}(\mathrm{v})$ the estimated number of workers to be laid off by each firm as a consequence of the increase in imports or shifts in production outside the United States; and, importantly, (vi) whether and when the petition is certified. The TAA approval decision is made by the U.S. DoL. Summary statistics for our dependent variable (CERTIFIED) and for the estimated number of

\footnotetext{
${ }^{5}$ According to the official TAA website supported by the Employment and Training Administration of the U.S. Department of Labor: "A [TAA] petition may be filed by a group of three or more workers, by a company official, by One-Stop operators or partners (including state employment security agencies and dislocated worker units), or by a union or other duly authorized representative of such workers. The workers on whose behalf a petition is filed must be, or have been, employed at the firm or subdivision identified in the petition."
} 
workers to be laid off ( $\left.E S T \_W R K R S\right)$ across the three dimensions in our data (2-digit SIC-Division-electoral period) are reported in the Appendix Tables.

Our main political covariates derive from the outcomes of the Presidential elections. These data come from Dave Leip's Atlas of U.S. Presidential Elections available at http://uselectionatlas.org/RESULTS/ and cover all U.S. states plus Washington D.C.. As discussed above, REPSTATE $E_{s, y}$ takes a value one if, in the last Presidential elections prior to year $y$, state $s$ voted Republican. $R E P P R E S_{y}$ is a dummy variable equal to one if the President in power belongs to the Republican Party.

In an additional robustness check, we also include political variables based on elections to the House of Representatives, the Senate, and gubernatorial elections. ${ }^{6}$ The variable REP_SENATE $E_{y}$ takes on a value of 1 if the majority of senators in year $y$ belonged to the Republican Party and zero otherwise. Similarly, REP_HOUSE $E_{y}$ equals 1 if the majority of members of the House of Representatives in year $y$ belonged to the Republican Party and zero otherwise. If the state governor belongs to the Republican Party, the variable $R E P \_G O V R N R_{s, y}$ takes on a value of 1 , whereas it equals 0 in case of a Democrat or independent governor (or Democrat mayor in the case of Washington D.C.). If the governor is an independent, the dummy variable OTHER_GOVRN $R_{s, y}$ equals 1. The variables $E L Y E A R_{-} S E N T R_{s, y}$ and $E L Y E A R_{-} G O V N R_{s, y}$ take on a value of 1 if year $y$ happened to be a senatorial or gubernatorial election year in state $s$, respectively. Senators are elected for six years, and regular senatorial elections take place every two years, leading to the reelection or replacement of one third of the senators. For gubernatorial elections, the regular cycle for elections varies by state. Finally, we also include two dummy variables for states that always voted for the same party in every Presidential election in our data. These variables are labeled $A L W A Y S D E M_{s}$ for always Democrat voting states (Minnesota and Washington D.C.) and $A L W A Y S R E P_{s}$

${ }^{6}$ These data were also taken from the Atlas of U.S. Presidential Elections in combination with the following internet sources: http://clerk.house.gov/member_info/electionInfo/, http://bioguide.congress.gov/biosearch/biosearch.asp, and apportionment data for the House are from http://www.census.gov/prod/cen2010/briefs/c2010br-08.pdf. 
for always Republican voting states (Alaska, Idaho, Indiana, Kansas, North Dakota, Nebraska, Oklahoma, South Dakota, Utah, Virginia, Wyoming).

The state data come from several sources. Gross domestic product and tax data at the state level are from the Bureau of Economic Analysis official web site. Population data and state data on unemployment and unionization rates are from the U.S. Census Bureau. The U.S. Census Bureau (http://www.census.gov/econ/cbp/) is also the source for our data at the state-industry level. The state level data on the number of establishments and employment by sector come from the County Business Patterns (CBP) database. We use the years 1986 to 2005. The industry level code utilized in the CBP data changes over the years: 1972 SIC for 1986-1987, 1987 SIC for 1988-1997, NAICS 1997 for 1998-2002, and NAICS 2002 for 2003-2005. Thus, we needed to map the data into a common industry classification. This process was done at the 4-digit level first to 1987 SIC. The 4-digit level was chosen as having a sufficiently disaggregated level to ensure major code changes could be taken into account. However, a significant fraction of the data (around 30\% in some years) at the disaggregated level (by year, state, and 4-digit industry code) is suppressed by the Census Bureau to protect firm identities. Unfortunately, this procedure results in a significant fraction of "zeros" in our data. Thus, we aggregate to the 2-digit level to better capture industry activity by state and year. That reduces the fraction of zeros to a much smaller number, though some zeros still remain.

We use a large set of industry-level control variables that measure industry production and industry trade. 4-digit SIC industry-level output, employment, payroll and other input costs, investment, capital stocks, TFP, and various industry-specific price indices are from the NBER-CES Manufacturing Industry Database. These data are created and maintained jointly by the National Bureau of Economic Research (NBER) and the U.S. Census Bureau's Center for Economic Studies (CES). 
Our trade covariates are at the 4-digit SIC industry level and include exports, imports, and tariffs in levels as well as the annual changes of each of these variables. In order to obtain a maximum number of observations at the 4-digit SIC level, we combine trade flows and protection data from several sources. The main source for imports and exports data is the United Nations Statistical Division (UNSD) Commodity Trade Statistics Database (COMTRADE). ${ }^{7}$ These data cover the period 1991-2005. In addition to COMTRADE, we utilize Feenstra's NBER databases, Feenstra (1996) and Feenstra (1997), which cover the period 1979-1990. Finally, we also use data from the United Nations Conference on Trade and Development (UNCTAD) Trade Analysis and Information System (TRAINS) to complement COMTRADE and the data from Feenstra. Our tariff data come from two sources. Tariff data until 1999 are taken from Peter Schott's web site. We complement these data with tariffs from TRAINS.

Summary statistics for the explanatory variables employed in our analysis, simultaneously averaged across all dimensions of the data, can be found in Table 1. Summary statistics for our dependent variable (Certified) by 2-digit SIC and by Division, by 2digit SIC and by electoral period, and by Division and by electoral period can be found in the Appendix. The complete data set is available upon request from the authors.

\section{A First Look: TAA Outcomes and Political Determinants}

Table 2 provides an overview of our sample displaying the number of cases by state (including Washington D.C.), the estimated number of laid-off workers claimed in the TAA petitions, and the actual share of TAA petitions which were certified. ${ }^{8}$ The state with the highest number of cases in the 1980 to 2005 period is Pennsylvania, a state with severe structural problems due to the decline in the coal and steel industries, followed

\footnotetext{
${ }^{7}$ We access COMTRADE through the World Integrated Trade Solution (WITS) software, http://wits.worldbank.org/witsweb/. The software reports trade data in three different concordances, including Harmonized System (HS) Revisions 1989/92 and 1996, and the Standard International Trade Classification (SITC), which are automatically converted to ISIC Rev. 2. To obtain a maximum number of observations, we combine the data from the different concordances.

${ }^{8}$ In addition, Table 2 groups the states into 'Always Republican', 'Always Democrat', and 'Swing' states.
} 
by New Jersey and New York. The lowest petition numbers come from Hawaii, North Dakota, and Washington D.C. (not surprisingly since it is the only city in our data set). In terms of the estimated number of laid-off workers, Michigan leads the ranking, followed by Ohio and Pennsylvania. Washington D.C., Kansas, and Wyoming report the lowest numbers. For petition success, measured as the percentage of estimated laid-off workers whose TAA petition was certified, the data paint a different picture. The most successful states are Mississippi, Alaska, and North Carolina with certification rates above $75 \%$, whereas Delaware and Wyoming are at the bottom end of the distribution with certification rates below $30 \%$.

Aggregating to Census divisions, ${ }^{9}$ Figure 1 shows that the highest number of TAA petitions come from the Middle Atlantic division (Div. 2), whereas the lowest number of cases are from the Mountain division (Div. 8). In terms of certification shares, the South Atlantic and East South Central divisions (Div. 5 and 6) are in the lead, whereas the lowest certification shares can be found in the East North Central and West South Central divisions (Div. 3 and 7).

Figure 2 splits up the sample by SIC-2 category. Here, we see that by far the most cases as well as the highest percentage of certified petitions come from the 'Apparel and Other Textile Products' sector (SIC 23). The lowest number of cases can be found in the 'Tobacco Products' industry (SIC 21), followed by the 'Petroleum and Coal Products' sector (SIC 29) and the 'Printing and Publishing' industry (SIC 27). 'Petroleum and Coal Products' is also the least successful sector in terms of certification rates by a discrete margin.

As a preliminary glance at politically driven TAA outcomes, we first look at the differences between states that voted for the candidate who won the prior Presidential election and those that voted for the losing candidate. The top panel of Figure 3 reports

\footnotetext{
${ }^{9}$ The Census divisions are: New England, Midatlantic, South Atlantic, East South Central, West South Central, East North Central, West North Central, Mountain, and Pacific.
} 
simple average certification rates according to this criterion. The figure paints a somewhat differentiated picture: states that voted for the President in power seem to have garnered more TAA support in the second half of the Reagan period as well as during both Bush administrations. During the first period of the Reagan administration, which was affected by the second oil crisis, as well as during the Clinton administration, there appears to be no bias for TAA petitions coming from states that voted for the President.

These results appear robust to a change in the weighting procedure for TAA certification. We calculate weighted average certification rates as:

$$
T A A_{-} A_{p p r o v a l \_} R_{a t} e_{s, y}=\frac{\sum_{c}\left[C E R T I F I E D_{c, s, i, y} \times E S T_{-} W R K R S_{c, s, i, y}\right]}{\sum_{c} E S T_{-} W R R S_{c, s, i, y}} .
$$

where CERTIFIE $D_{c, s, i, y}$ is our dependent variable, which takes a value of one if a TAA petition $c$ filed in year $y$ in state $s$ is certified by the U.S. DoL, and it is equal to zero otherwise; and EST_WRKRS $S_{c, s, i, y}$ is the estimated number of workers who will be laid off in a petition case $c$ in industry $i$ in state $s$ in year $y$ due to trade. In the bottom panel of Figure 3, once again we see that during the second electoral term of the Reagan administration and the Bush administrations, Republican states are favored. During the Clinton administration, however, the Republican states continued to have higher success rates than the Democrat states. These findings imply that Republican states on average receive more TAA support regardless of who is in power. The two panels of Figure 4 confirm this finding. Figure 4 plots, respectively, the simple average (top panel) and the weighted average (bottom panel) certification rates for Republican vs. Democrat states.

Next, we identify those states that always voted Democrat (Washington D.C., Minnesota) during the period 1980 to 2005 and those that always voted Republican (Alaska, Idaho, Indiana, Kansas, North Dakota, Nebraska, Oklahoma, South Dakota, Utah, Virginia, Wyoming) in the Presidential elections. The top and the bottom panels of Figure 5 report simple and weighted average certification probabilities, respectively. We see 
that the certification probability is typically higher for always Republican voting states as compared to states that always voted for a Democrat in Presidential elections.

Based on the preliminary descriptive statistics presented in this section, it appears that the administration's TAA decisions exhibit a bias towards Republican states. One has to keep in mind, however, that the TAA certification process should reflect whether a certain industry in a particular year was negatively affected, for example, by import competition. Without controlling for other factors that should or could influence the certification decision, the above relationships and analysis are only suggestive, and by no means a proof that the TAA administration reflects or does not reflect a political bias. Therefore, in order to investigate the issue further and to establish causal relationships between political influence and TAA certification, next we conduct an econometric analysis controlling for other possible determinants of the TAA decision process.

\section{ECONOMETRIC Findings}

6.1. Main Results. We start with a base specification that only includes our political dummy variables and a time trend. Estimation results are reported in column (1) of Table 3. All included variables have a statistically significant (at least at the 5\% level) effect on the certification probability. The following findings stand out. First, the estimate of the coefficient on REPPRES is negative and statistically significant, meaning that Republican Presidents are less likely to grant TAA. Second, the estimate of the coefficient on the indicator variable REPSTATE is positive and significant. All else equal, TAA petitions from Republican states are more likely to be certified. This result is in accordance with the analysis from the previous section. Third, the interaction term between REPPRES and REPSTATE is also positive and statistically significant. Fourth, the certification probability increases in Presidential election years. An intuitive explanation for this result is that politicians are more sensitive to voters' needs during election years. Finally, we obtain a positive and significant estimate of the coefficient of 
the time trend in our specification, which suggests that the number of certified petitions increased over the period of investigation.

Column (2) of Table 3 reports the results from a specification where the estimated number of laid-off workers as well as trade-related control variables which we consider the main direct determinants of the TAA certification outcomes are added to the political variables from Column (1). Specifically, we include as explanatory variables the estimated number of workers $\left(E S T_{-} W R K R S\right)$ to be laid-off due to trade, 4-digit industry imports (IMPORTS) and their change (CHNGE_IMPORTS), exports (EXPORTS) and their change (CHNGE_EXPORTS) and tariffs (TARIFFS) and their change (CHNGE_TARIFFS). The addition of the estimated number of workers to the econometric specification is motivated by our theoretical model. We include imports, exports, and their changes because these variables are the key variables that are taken into account by the government during the TAA certification process to determine the competitive position of an industry in the world market, at least according to the letter of the law. A similar argument could be made for the inclusion of tariffs. Magee (2001) makes an alternative compelling argument for why tariffs should affect the probability for TAA certification. Magee's idea is that "the government uses TAA to compensate workers for lost tariff protection. Consistent with this argument, a decline in tariffs over the previous year raises workers' chances of receiving adjustment assistance." (Magee, 2001, p.105) Accordingly, we expect to find that the probability for TAA certification is higher in industries with high tariffs. We also note that the number of observations decreases from 43, 157 to 35,634 due to trade protection data availability at the sectoral level.

Concerning the econometric findings in column (2) of Table 3, several results stand out. First, and most important for our purposes, we find that all political variables retain their sign and statistical significance and that their magnitudes remain relatively stable, too. In addition, we find that the number of workers who will be laid off due 
to trade is positively related to the probability for TAA certification. Our intuition is that the positive and significant coefficient on $E S T_{-} W R K R S$ is due to the fact that a larger number of estimated workers to be laid off due to trade reflects stronger import competition and a higher urgency for officials to react and offer support, outweighing the diminishing returns to re-employment.

The estimates on all the trade variables are also in accordance with our prior expectations. All else equal, larger imports and larger import changes result in a larger probability for TAA certification. The DoL takes into account these key variables during the certification process. Larger imports and a larger increase in imports put more pressure on domestic production and translate into a larger number of layoffs due to trade, which motivates the government to certify more TAA petitions. Also as expected, we find that, all else equal, less TAA petitions are certified for industries with larger exports and a larger increase in exports. The intuitive explanation is that better export performance is an indicator of good competitive standing and, therefore, no reason to justify layoffs due to import competition.

Finally, we obtain positive and significant estimates on tariffs and their changes. The first result with respect to protection is exactly in accordance with the intuition from Magee (1997) and Magee (2001), which predict that the DoL should be more likely to certify workers the higher the tariff in their industry. Our positive and significant estimate on the coefficient of tariff changes does not support the intuitive argument that "trade adjustment assistance can be used as a payment to labor groups in order to lessen the harm done when tariff cuts lead to increased imports." (Magee, 2001, p.113) Magee (2001) himself finds only tentative support for this hypothesis as the estimates of the coefficient on tariff change in his model vary between -0.017 and 0.030 across specifications. In our case, the estimate on $C H N G E \_T A R I F F S$ is strictly positive and highly statistically significant, suggesting a higher probability for certification in industries with higher tariff increases or smaller tariff cuts. This result can be interpreted 
as suggestive of joint usage of tariff protection and TAA in order to dampen the impact of adverse economic conditions.

In column (3) of Table 3, we add state and industry fixed effects in order to control for any observable and unobservable state and industry characteristics that may affect the probability for TAA certification, but have been omitted from our econometric model. The results from column (3) remain very similar to the corresponding estimates from columns (1) and (2). The only notable difference is that the statistical significance of the coefficient on the interaction term between REPPRES and REPSTATE drops from $1 \%$ to $10 \%$. However, the estimates of the coefficient on the interaction term from columns (2) and (3) are not statistically different from each other.

We finish our main estimation analysis with the specification from column (4) of Table 3, where we add a series of state-year, industry-year and industry-state-year variables that may influence the government decision to grant a TAA certification. The state-year variables include average unemployment rate (STATE_UNEMPL), union coverage density (STATE_UNION), GDP per capita $\left(G D P \_C A P\right)$, compensation of employees (EMPL_COMP), subsidies (SUBSIDIES), and taxes on production and imports less subsidies (NET_TAXES). The industry-year variables come from the detailed NBER-CES database and include total employment (EMPLOYMENT), total payroll ( $P A Y R O L L)$, production workers $\left(P R D C N_{-} W R K R S\right)$, total value of shipments (VALUE_SHIPMENTS), total value added (VALUE_ADDED), total capital expenditure (INVESTMENT), cost of electricity and fuels (ENERGY_COST), total real capital stock ( $\left.C A P I T A L \_S T O C K\right)$, the 5-factor TFP index (TFP5), and the 5-factor TFP annual growth rate (CHNGE_TFP5). Finally, we add controls at the state-industry-year level, which include total employment (EMPL_IND_STATE), total annual payroll ( $\left.P A Y R O L_{-} I N D_{-} S T A T E\right)$, and total number of establishments $\left(E T B L S H \_I N D \_S T A T E\right)$. 
The estimates from column (4) reveal that our main findings concerning the political determinants of TAA certification remain robust with respect to the sign and economic magnitude. However, we also see that most of the estimates on the political variables lose statistical significance except for REPPRES. We attribute the loss in statistical significance to the sharp decrease of observations (from more than 35,000 to less than $23,000)$ due to a combination of missing data among the new covariates.

The estimates of the new covariates are mostly intuitive. They suggest that, ceteris paribus, the government is more likely to approve TAA petitions from states with higher unemployment rates, higher GDP per capita, higher payroll and higher net taxes. Higher employment and higher employee compensation at the industry level have a negative impact. We also find that certification is more likely in industries with lower investment, higher energy costs and lower capital stock. The coefficients on these variables appear to reflect the characteristics of industries most vulnerable to import competition during the time period under study which coincides with the aftermath of the energy crises of the 1970 s and early 1980 s and the decline in the manufacturing sector. The effect of total factor productivity is positive, however. A larger number of employed per industry and state suggests potentially increasing costs of providing TAA.

In order to quantify and compare the effects of different combinations of Presidency and state Presidential election results on the TAA certification probability, we construct average marginal effects. Table 4 reports the findings. The top panel summarizes the effects of changes in state Presidential elections by Presidential affiliation, while the bottom panel reports the effects of changes in Presidency by state Presidential election result. The column labels in each table correspond to the column labels from Table 3.

The estimates in the top panel of Table 4 reveal that a switch from Democrat to Republican state increases the probability of certification regardless of whether the President is Republican or not, but the effect is more than double when the President comes from the Republican party $(2.2$ to $2.9 \%$ for a Democrat President compared to 
estimates of 4.7 to $8.4 \%$ for a Republican President), and the estimates are more precise. In our specification with TAA variables and state and industry fixed effects (column (3)), a change from Democrat to Republican voting state increases the certification probability by $2.2 \%$, significant at the $5 \%$ level, if the President is a Democrat, whereas the certification probability increases by $4.7 \%$, statistically significant at the $1 \%$ level, if the President is a Republican. The latter effect remains statistically significant at the $1 \%$ level and even increases in size to $6.1 \%$ if all controls are added.

In the bottom panel of Table 4, the average marginal effects of changes from a Democrat to a Republican President are negative and highly statistically significant. In addition, an interesting political difference emerges: The reduction in certification probability is considerably smaller for states that voted Republican than for those who voted Democrat. A change from a Democrat to a Republican President reduces the certification probability by $8.1 \%$ if the state voted Democrat in the last Presidential election, but by only $5.6 \%$ if the state voted Republican, as column (3) shows. These effects remain statistically significant and even increase in size if all controls are added (column (4)).

6.2. Robustness Checks. Motivated by the strong political influence on TAA certification documented thus far, in the following analysis we dig deeper by introducing additional political variables pertaining to the composition of Congress (Senate and House of Representatives) and the governor's party affiliation. As a baseline specification, we use our main estimates from column (3) of Table 3, which include the original political variables, the trade variables, and the two sets of state and industry fixed effects. For ease of comparison, we provide these estimation results again in column (1) of Table 5, where we also report the results from four additional specifications.

The estimates in column (2) of Table 5 are obtained after adding a dummy variable for a Republican majority in the Senate $R E P{ }_{-} S E N A T E_{y}$, an interaction term of this variable with Republican Presidency $R E P P R E S_{y}$ and the election year dummy 
ELYEAR_SENTR $R_{s, y}$ which equals 1 if either of the two Senate seats of the state is up for reelection. In column (3) of Table 5, we keep the new Senate-related variables and we add a dummy variable for a Republican majority in the House of Representatives REP_HOUSE $E_{y}$ as well as an interaction term with $R E P P R E S_{y}$. Next, in column (4), we introduce as additional covariates the dummy variables $R E P \_G O V R N R_{s, y}$ and $O T H E R_{-} G O V R N R_{s, y}$ plus the corresponding interaction terms with $R E P P R E S_{y}$, and an election year dummy ELYEAR_GOVNR $R_{s, y}$, and finally we also introduce the dummy variables $A L W A Y S D E M_{s}$ and $A L W A Y S R E P_{s}$ for states that always voted for the same party in Presidential elections plus interaction terms with REPPRES .

The new specifications in columns (2) to (5) of Table 5 depict some common and distinguishable patterns, but also offer new insights about the effects of political influence on TAA certification. Overall, we confirm that the influence of the original political variables is strong and the effects that we obtain in the new specifications are quite similar to the main estimates from Table 3. Two changes are worth a mention. First, we note that the negative impact of Republican Presidency on the TAA certification probability approximately doubles when the new political variables are introduced, and the significance level remains at $1 \%$. Second, we find that the estimate on the interaction term REPPRES*REPSTATE gains significance when the additional 'Senate' variables are introduced in column (2), but loses significance when all new political covariates are added at the same time in column (5).

Turning to the effects of the new political variables, we find the following. The estimates from column (2) reveal that a Republican-dominated Senate itself reduces the certification probability, but the interaction with Republican Presidency is positive. Both effects are highly significant. The results from column (3) suggest that a Republican-dominated House does not seem to influence the TAA certification probability; however, we find that the interaction term with Republican Presidency is negative and highly statistically significant. The estimates from column (4) imply that if the 
governor of a state is a Republican, the certification probability increases, although the effect is rather moderate in size and only statistically significant at the $5 \%$ level. The interaction term, however, is highly statistically significant with a negative sign. Finally, the prior would be that workers in states that always vote for the same party in Presidential elections may be less likely to receive TAA since it is unlikely that TAA certification changes the state's voting pattern. This expectation is partly validated by the negative and sizable coefficients for $A L W A Y S D E M_{s}$ and $A L W A Y S R E P_{s}$ that we obtain in column (5) of Table 5, but only $A L W A Y S D E M_{s}$ is statistically significant at the $10 \%$ level. The interactions with Republican Presidency are positive, but only the interaction with always Republican voting states is moderately statistically significant at the $10 \%$ level.

The numbers in Table 6, which are based on the estimation results reported in Table 5, show the average marginal effects for Republican and Democrat Presidency when a state switches from Democrat to Republican voting outcome in Presidential elections (Panel A of Table 6), when the Senate or the House of Representatives changes from Democrat to Republican majority (Panel B and Panel C of Table 6), and when the party affiliation of the state governor changes (Panels D and E of Table 6). Under a Democrat Presidency, a state switch to Republican voting in Presidential elections increases the certification probability by 2 to $4 \%$ with levels of significance varying between 1 and $10 \%$. This increase approximately doubles and becomes highly statistically significant for a Republican Presidency. A switch from a Democrat to a Republican Senate majority decreases the certification probability by 3 to $6 \%$ when the President is a Democrat, whereas under a Republican Presidency, the certification probability rises by 6 to $10 \%$. Both types of marginal effects are statistically significant at the $1 \%$ level. When the House of Representatives switches from a Democrat to a Republican majority, only the effects under a Republican Presidency are statistically significant, but the estimated effect is relatively large (9 to 10\%) and precisely estimated (statistical significance at the 
$1 \%$ level). For governor, only the marginal effects of a change to a Republican governor are statistically significant. If the President is a Democrat, a change to a Republican state governor increases the probability of TAA certification by $2 \%$, whereas under a Republican Presidency, the probability is reduced by almost $2 \%$.

\section{Conclusion}

Guided by the main technical criteria used by the U.S. government in the official TAA certification process and by related contributions in the academic literature, we control for a series of factors, such as the level and the change in industry exports and imports, the level and change in industry tariffs, as well as state unemployment and unionization rates, number of establishments, etc. We also experiment with a rich set of fixed effects to control for various characteristics across the three dimensions of our data that may affect the government's decision to certify a TAA petition. Our main finding is that even after including a wide array of controls, political influences on the TAA certification still are apparent. We find that a switch from Democrat to Republican Presidency reduces the probability to receive TAA, but the reduction in certification probability is less pronounced for Republican states. At the same time, a switch from a Democrat to Republican voting state makes it more likely for workers to be certified for TAA, and the rise in certification probability is higher under Republican Presidency.

\section{REFERENCES}

Baicker, K., And M. M. Rehavi (2004): "Policy Watch: Trade Adjustment Assistance," Journal of Economic Perspectives, 18, 239-255.

Dutt, P., And D. Mitra (2005): "Political Ideology and Endogenous Trade Policy: An Empirical Investigation," Review of Economics and Statistics, 87, 59-72.

Feenstra, R. C. (1996): "U.S. Imports, 1972-1994: Data and Concordances," NBER Working Papers, 5515.

_ (1997): "U.S. Exports, 1972-1994: With State Exports and Other U.S. Data," NBER Working Papers, 5990.

Gawande, K., and U. Bandyopadhyay (2000): "Is Protection for Sale? Evidence on the Grossman-Helpman Theory of Endogenous Protection," Review of Economics and Statistics, 82, 139-152. 
Goldberg, P. K., and G. Maggi (1999): "Protection for Sale: An Empirical Investigation," American Economic Review, 89, 1135-1155.

Grossman, G. M., and E. Helpman (1994): "Protection for Sale," American Economic Review, 84, 833-850.

HornBeCK, J. F. (2013): "Trade Adjustment Assistance (TAA) and Its Role in U.S. Trade Policy," Congressional Research Service Report for Congress R41922.

Kondo, I. O. (2013): "Trade Reforms, Foreign Competition, and Labor Market Adjustments in the U.S.," International Finance Discussion Papers 1095, Board of Governors of the Federal Reserve System (U.S.).

MageE, C. (1997): "Tariffs and Trade Adjustment Assistance for Declining Industries," Dissertation, University of Wisconsin-Madison.

- (2001): "Administered Protection for Workers: An Analysis of the Trade Adjustment Assistance Program," Journal of International Economics, 53, 105-125.

Marcal, L. E. (2001): "Does Trade Adjustment Assistance Help Trade-Displaced Workers?," Contemporary Economic Policy, 19, 59-72.

Matschke, X. (2010): "Do Labor Market Imperfections Increase Trade Protection? A Theoretical Investigation," B.E. Journal of Economic Analysis and Policy: Topics, 10(1), Article 50.

Matschke, X., And S. M. Sherlund (2006): "Do Labor Issues Matter in the Determination of U.S. Trade Policy? An Empirical Reevaluation," American Economic Review, 96, 405-421.

Melitz, M. J. (2003): "The Impact of Trade on Intra-Industry Reallocations and Aggregate Industry Productivity," Econometrica, 71(6), 1695-1725.

Palatucci, J. S., And K. M. Reynolds (2012): "Does Trade Adjustment Assistance Make a Difference?," Contemporary Economic Policy, 30, 43-59.

Uysal, P., Y. V. Yotov, And T. ZYlkin (2015): "Firm heterogeneity and tradeinduced layoffs: An empirical investigation," European Economic Review, 75(C), 8097.

Yotov, Y. V. (2010): "Trade-Induced Unemployment: How Much Do We Care?," Review of International Economics, 18, 972-989.

(2013): "Trade Adjustment, Political Pressure, and Trade Protection Patterns," Economic Inquiry, 51, 1867-1885. 


\section{TABles AND Figures}

TABLE 1. Summary statistics

\begin{tabular}{|c|c|c|c|}
\hline$\overline{\text { Variable }}$ & Mean & Std. Dev. & $\overline{\bar{N}}$ \\
\hline REPPRES & 0.720 & 0.449 & 43157 \\
\hline REPSTATE & 0.649 & 0.477 & 43157 \\
\hline ELYEAR_PRES & 0.252 & 0.434 & 43157 \\
\hline REP_SENATE & 0.596 & 0.491 & 43157 \\
\hline REP_HOUSE & 0.420 & 0.494 & 43157 \\
\hline REP_GOVRNR & 0.507 & 0.524 & 43157 \\
\hline ELYEAR_GOVNR & .256 & 0.436 & 43157 \\
\hline EST_WRKRS & 0.131 & 0.385 & 43106 \\
\hline IMPORTS & 17.244 & 3.481 & 37865 \\
\hline CHNGE_IMPORTS & -0.032 & 1.335 & 37861 \\
\hline EXPORTS & 16.749 & 3.591 & 39981 \\
\hline CHNGE_EXPORTS & -0.132 & 1.211 & 39981 \\
\hline TARIFFS & 6.443 & 7.064 & 38735 \\
\hline CHNGE_TARIFFS & -0.223 & 1.11 & 37749 \\
\hline STATE_UNEMPL & 6.362 & 2.139 & 43157 \\
\hline STATE_UNION & 19.716 & 8.452 & 43157 \\
\hline GDP_CAP & 25.153 & 9.694 & 43157 \\
\hline EMPL_COMP & 138.294 & 131.46 & 38083 \\
\hline SUBSIDIES & -1.141 & 1.451 & 38083 \\
\hline NET_TAXES & 16.55 & 15.881 & 38083 \\
\hline EMPLOYMENT & 90.589 & 111.214 & 40707 \\
\hline PAYROLL & 2.638 & 3.758 & 40707 \\
\hline PRDCN_WRKRS & 0.067 & 0.084 & 40707 \\
\hline VALUE_SHIPMENTS & 16.571 & 28.214 & 40707 \\
\hline VALUE_ADDED & 6.94 & 10.672 & 40707 \\
\hline INVESTMENT & 0.629 & 1.21 & 40707 \\
\hline ENERGY_COST & 0.373 & 0.898 & 40707 \\
\hline CAPITAL_STOCK & 9.040 & 15.839 & 40707 \\
\hline TFP5 & 1.319 & 2.384 & 40707 \\
\hline CHNGE_TFP5 & 0.006 & 0.08 & 40707 \\
\hline EMPL_IND_STATE & 0.085 & 0.107 & 34394 \\
\hline PAYROL_Y_IND_STATE & 0.637 & 0.975 & 34394 \\
\hline ETBLSH_IND_STATE & 1.670 & 2.391 & 34394 \\
\hline
\end{tabular}

Notes: This table reports summary statistics for the main covariates in our model. Summary statistics for the dependent variable by state can be found in Table 2 . The complete data set is available by request. 
TABle 2. TAA Cases by State and Voting Category

\begin{tabular}{|c|c|c|c|}
\hline state & cases & est. laid-off workers (1000s) & share certified workers \\
\hline \multicolumn{4}{|c|}{ Always Republican Voting States } \\
\hline AK & 43 & 4.481 & .785539 \\
\hline ID & 181 & 21.009 & .6582893 \\
\hline IN & 1107 & 221.695 & .4938226 \\
\hline KS & 195 & 50.105 & .5565313 \\
\hline ND & 36 & .666 & .4489489 \\
\hline $\mathrm{NE}$ & 82 & 7.824 & .7317229 \\
\hline OK & 398 & 68.314 & .4622625 \\
\hline SD & 43 & 6.654 & .6175234 \\
\hline UT & 170 & 27.127 & .5874959 \\
\hline VA & 824 & 111.411 & .6719982 \\
\hline WY & 37 & 1.133 & .2930274 \\
\hline \multicolumn{4}{|c|}{ Always Democrat Voting States } \\
\hline DC & 9 & .163 & .607362 \\
\hline MN & 657 & 62.165 & .4705863 \\
\hline
\end{tabular}

Swing States

\begin{tabular}{|c|c|c|c|}
\hline $\mathrm{AL}$ & 811 & 121.75 & .7348994 \\
\hline $\mathrm{AR}$ & 503 & 65.608 & .6293592 \\
\hline $\mathrm{AZ}$ & 316 & 46.126 & .3935958 \\
\hline $\mathrm{CA}$ & 1422 & 225.872 & .5927871 \\
\hline $\mathrm{CO}$ & 394 & 45.893 & .5616978 \\
\hline $\mathrm{CT}$ & 620 & 80.626 & .3852603 \\
\hline $\mathrm{DE}$ & 45 & 11.705 & .2000854 \\
\hline FL & 564 & 59.493 & .6057519 \\
\hline GA & 987 & 160.55 & .6855435 \\
\hline HI & 29 & 2.333 & .4144878 \\
\hline IA & 276 & 31.929 & .4976354 \\
\hline IL & 1181 & 174.483 & .520853 \\
\hline KY & 678 & 109.285 & .6258681 \\
\hline LA & 243 & 36.375 & .716536 \\
\hline MA & 1296 & 139.093 & .5181785 \\
\hline MD & 338 & 58.836 & .5756 \\
\hline ME & 747 & 51.333 & .6498549 \\
\hline MI & 2873 & 653.142 & .6111856 \\
\hline $\mathrm{MO}$ & 1015 & 153.301 & .6164735 \\
\hline MS & 456 & 60.511 & .8227926 \\
\hline MT & 123 & 10.309 & .4277815 \\
\hline $\mathrm{NC}$ & 1742 & 189.677 & .7784339 \\
\hline $\mathrm{NH}$ & 200 & 21.401 & .5678707 \\
\hline NJ & 3528 & 280.761 & .3868628 \\
\hline NM & 90 & 8.383 & .6201836 \\
\hline NV & 54 & 1.972 & .5314401 \\
\hline NY & 3324 & 306.774 & .6057 \\
\hline $\mathrm{OH}$ & 2599 & 454.305 & .5054094 \\
\hline OR & 878 & 87.12 & .4844238 \\
\hline PA & 4506 & 439.674 & .496643 \\
\hline RI & 331 & 25.875 & .6531014 \\
\hline $\mathrm{SC}$ & 656 & 95.027 & .7186063 \\
\hline $\mathrm{TN}$ & 1497 & 198.796 & .6475231 \\
\hline $\mathrm{TX}$ & 2197 & 316.2 & .4738298 \\
\hline VT & 116 & 8.013 & .604892 \\
\hline WA & 1001 & 123.777 & .4891458 \\
\hline WI & 1373 & 183.486 & .4717417 \\
\hline WV & 366 & 45.465 & .4426482 \\
\hline
\end{tabular}

Notes: This table reports summary statistics by state for the number of cases filed for TAA certification, for the number of workers to be laid off due to trade, and for the TAA certification rate (as percentage of the filed cases). More summary statistics for the dependent variable across various dimensions are reported in the supplementary Appendix. The complete data set is available by request. In addition, the table splits the states into those that always voted 'Republican', those that always voted 'Democrat', and 'Swing' states. 
TABle 3. TAA, Presidency, and Presidential Election Results by State

\begin{tabular}{|c|c|c|c|c|}
\hline & $\begin{array}{c}\text { (1) } \\
\text { Polit. Vars. }\end{array}$ & $\begin{array}{c}(2) \\
\text { Trade Vars }\end{array}$ & $\begin{array}{c}\text { (3) } \\
\text { Fixed Effects }\end{array}$ & $\begin{array}{c}(4) \\
\text { Control Vars }\end{array}$ \\
\hline REPPRES & -0.482 & -0.449 & -0.398 & -0.483 \\
\hline PEDSTATE & $(0.036)^{* *}$ & $(0.043)^{* *}$ & $(0.047)^{* *}$ & $(0.082)^{* *}$ \\
\hline REPSTATE & 0.105 & 0.113 & 0.112 & 0.148 \\
\hline REPPRES*REPSTATE & 0.268 & 0.162 & 0.117 & $\begin{array}{l}(0.125) \\
0.143\end{array}$ \\
\hline & $(0.051)^{* *}$ & $(0.059)^{* *}$ & $(0.064)^{+}$ & $(0.127)$ \\
\hline ELYEAR_PRES & 0.147 & 0.189 & 0.169 & 0.058 \\
\hline & $(0.024)^{* *}$ & $(0.028)^{* *}$ & $(0.029)^{* *}$ & $(0.040)$ \\
\hline YEAR & 0.081 & 0.099 & 0.099 & 0.007 \\
\hline EST_WRKRS & $(0.001)^{* *}$ & $\begin{array}{c}(0.003)^{* *} \\
0.214\end{array}$ & $\begin{array}{c}(0.003)^{* *} \\
0.229\end{array}$ & $\begin{array}{c}(0.018) \\
0.019\end{array}$ \\
\hline & & $(0.031)^{* *}$ & $(0.038)^{* *}$ & $(0.055)$ \\
\hline IMPORTS & & 0.338 & 0.280 & 0.242 \\
\hline & & $(0.009)^{* *}$ & $(0.010)^{* *}$ & $(0.017)^{* *}$ \\
\hline CHNGE_IMPORTS & & 0.338 * & 0.277 * & 0.320 \\
\hline EXPORTS & & -0.288 & -0.204 & -0.163 \\
\hline CHNGE_EXPORTS & & $\begin{array}{l}(0.009)^{* *} \\
-0.298 \\
\end{array}$ & $\begin{array}{l}(0.012)^{* *} \\
-0.224\end{array}$ & $\begin{array}{l}(0.017)^{* *} \\
-0.249\end{array}$ \\
\hline TARIFFS & & $\begin{array}{c}(0.020)^{* *} \\
0.047\end{array}$ & $\begin{array}{c}(0.021)^{* *} \\
0.019\end{array}$ & $\begin{array}{c}(0.035)^{* *} \\
0.018\end{array}$ \\
\hline & & $(0.002)^{* *}$ & $(0.003)^{* *}$ & $(0.004)^{* *}$ \\
\hline CHNGE_TARIFFS & & 0.067 & 0.059 & 0.039 \\
\hline STATE_UNEMPL & & $(0.011)^{* *}$ & $(0.011)^{* *}$ & $\begin{array}{c}(0.018)^{*} \\
0.042 \\
(0.016)^{*}\end{array}$ \\
\hline STATE_UNION & & & & $\begin{array}{c}0.010 \\
(0.015)\end{array}$ \\
\hline GDP_CAP & & & & 0.071 \\
\hline EMPL_COMP & & & & $\begin{array}{l}-0.007 \\
(0.001)^{* *}\end{array}$ \\
\hline SUBSIDIES & & & & -0.063 \\
\hline NET_TAXES & & & & 0.052 \\
\hline EMPLOYMENT & & & & $\begin{array}{l}(0.010) \\
-0.004\end{array}$ \\
\hline PAYROLL & & & & $\begin{array}{c}(0.001)^{* *} \\
0.151\end{array}$ \\
\hline PRDCN_WRKRS & & & & 0.940 \\
\hline VALUE_SHIPMENTS & & & & $\begin{array}{l}(1.114) \\
-0.004\end{array}$ \\
\hline VALUE_ADDED & & & & $\begin{array}{l}-0.002 \\
(0.007)\end{array}$ \\
\hline INVESTMENT & & & & $\begin{array}{l}-0.109 \\
(0.035)^{* *}\end{array}$ \\
\hline ENERGY_COST & & & & $\begin{array}{c}0.193 \\
(0.047)^{* *}\end{array}$ \\
\hline CAPITAL_STOCK & & & & $\begin{array}{c}-0.022 \\
(0.004)^{* *}\end{array}$ \\
\hline TFP5 & & & & $\begin{array}{c}0.036 \\
(0.009)^{* *}\end{array}$ \\
\hline CHNGE_TFP5 & & & & 0.199 \\
\hline EMPL_IND_STATE & & & & $\begin{array}{l}(0.201) \\
-1.769\end{array}$ \\
\hline PAYROL_Y_IND_STATE & & & & $\begin{array}{c}(0.686)^{* *} \\
0.123\end{array}$ \\
\hline ETBLSH_IND_STATE & & & & $\begin{array}{c}(0.069)^{+} \\
-0.007 \\
(0.012)\end{array}$ \\
\hline $\begin{array}{l}N \\
\text { state \& ind. FE }\end{array}$ & $\begin{array}{c}43157 \\
\text { no }\end{array}$ & $\begin{array}{c}35634 \\
\text { no }\end{array}$ & $\begin{array}{c}35634 \\
\text { ves }\end{array}$ & 22528 \\
\hline
\end{tabular}

Notes: This table reports our main estimation results. Column (1) includes only the main political variables. Column (2) introduces various trade variables. Column (3) adds state and industry fixed effects. Column (4) introduces additional control variables. Standard errors in parentheses ${ }^{+} p<0.10$, ${ }^{*} p<.05,{ }^{* *} p<.01$. See text for further details. 
TABle 4. Marginal Effects: Presidential Elections

\begin{tabular}{lcccc}
\hline \hline \multicolumn{7}{c}{$(1)$} & $(2)$ & $(3)$ & $(4)$ \\
A. Changes in State Presidential Elections by Presidential Affiliation & \\
(REPSTATE changes from 0 to 1) & & & & \\
\hline at REPPRES=0 & 0.023 & 0.023 & 0.022 & 0.029 \\
& $(0.009)^{*}$ & $(0.010)^{*}$ & $(0.011)^{*}$ & $(0.024)$ \\
at REPPRES=1 & 0.084 & 0.058 & 0.047 & 0.061 \\
& $(0.007)^{* *}$ & $(0.007)^{* *}$ & $(0.009)^{* *}$ & $(0.012)^{* *}$ \\
\hline \hline
\end{tabular}

B. Changes in Presidency by State Presidential Election Result

(REPPRES changes from 0 to 1 )

\begin{tabular}{lcccc}
\hline at REPSTATE $=0$ & -0.108 & -0.094 & -0.081 & -0.099 \\
at REPSTATE $=1$ & $(0.008)^{* *}$ & $(0.009)^{* *}$ & $(0.009)^{* *}$ & $(0.016)^{* *}$ \\
& -0.047 & -0.059 & -0.056 & -0.067 \\
& $(0.008)^{* *}$ & $(0.009)^{* *}$ & $(0.010)^{* *}$ & $(0.022)^{* *}$ \\
\hline$N$ & & & & \\
\hline \hline
\end{tabular}

Notes: This table reports average marginal effects constructed from the estimates in Table 3. Panel A reports the effects of changes in state presidential elections by presidential affiliation. Panel B reports the effects of changes in Presidency by state Presidential election result. The column labels refer to those in Table 3. Standard errors in parentheses. ${ }^{+} p<0.10,{ }^{*} p<.05$, ${ }^{* *} p<.01$ 
TABle 5. TAA, Presidency and Congress, Presidential Elections by State, Gubernatorial Elections

\begin{tabular}{|c|c|c|c|c|c|}
\hline & $\begin{array}{l}(1) \\
\text { Main }\end{array}$ & $\begin{array}{c}(2) \\
\text { Senate }\end{array}$ & $\begin{array}{c}(3) \\
\text { House }\end{array}$ & $\begin{array}{c}(4) \\
\text { Govnr }\end{array}$ & $\begin{array}{c}(5) \\
\text { Always }\end{array}$ \\
\hline \multirow[t]{2}{*}{ REPPRES } & -0.398 & -0.790 & -0.809 & -0.728 & -0.727 \\
\hline & $\begin{array}{c}(0.047)^{* *} \\
0.112\end{array}$ & $\begin{array}{c}(0.067)^{* *} \\
0.107\end{array}$ & $\begin{array}{c}(0.075)^{* *} \\
0.145\end{array}$ & $\begin{array}{c}(0.080)^{* *} \\
0.145\end{array}$ & $\begin{array}{c}(0.080)^{* *} \\
0.184\end{array}$ \\
\hline REPSTATE & $(0.057)^{*}$ & $(0.056)^{+}$ & $(0.057)^{*}$ & $(0.058)^{*}$ & $(0.062)^{* *}$ \\
\hline \multirow[t]{2}{*}{ REPPRES*REPSTATE } & 0.117 & 0.195 & 0.119 & 0.132 & 0.094 \\
\hline & $(0.064)^{+}$ & $(0.065)^{* *}$ & $(0.068)^{+}$ & $(0.068)^{+}$ & $(0.074)$ \\
\hline \multirow[t]{2}{*}{ ELYEAR_PRES } & 0.169 & 0.205 & 0.228 & 0.232 & 0.231 \\
\hline & $(0.029)^{* *}$ & $(0.036)^{* *}$ & $(0.037)^{* *}$ & $(0.038)^{* *}$ & $(0.038)^{* *}$ \\
\hline \multirow{2}{*}{ YEAR } & 0.099 & 0.105 & 0.129 & 0.126 & 0.127 \\
\hline & $(0.003)^{* *}$ & $(0.003)^{* *}$ & $(0.006)^{* *}$ & $(0.006)^{* *}$ & $(0.006)^{* *}$ \\
\hline EST_WRKRS & 0.229 & 0.235 & 0.240 & 0.237 & 0.236 \\
\hline \multirow[t]{2}{*}{ IMPORTS } & $\begin{array}{r}(0.038) \\
0.280\end{array}$ & $\begin{array}{r}(0.038) \\
0.293\end{array}$ & $\begin{array}{c}(0.039) \\
0.288\end{array}$ & $\begin{array}{c}(0.039) \\
0.287\end{array}$ & $\begin{array}{c}(0.039) \\
0.287\end{array}$ \\
\hline & $(0.010)^{* *}$ & $(0.010)^{* *}$ & $(0.010)^{* *}$ & $(0.010)^{* *}$ & $(0.010)^{* *}$ \\
\hline \multirow[t]{2}{*}{ CHNGE_IMPORTS } & 0.277 & 0.240 & 0.239 & 0.235 & 0.236 \\
\hline & $(0.020)^{* *}$ & $(0.021)^{* *}$ & $(0.021)^{* *}$ & $(0.021)^{* *}$ & $(0.021)^{* *}$ \\
\hline \multirow[t]{2}{*}{ EXPORTS } & -0.204 & -0.196 & -0.187 & -0.189 & -0.189 \\
\hline & $(0.012)^{* *}$ & $(0.012)^{* *}$ & $(0.012)^{* *}$ & $(0.012)^{* *}$ & $(0.012)^{* *}$ \\
\hline \multirow{2}{*}{ CHNGE_EXPORTS } & -0.224 & -0.207 & -0.197 & -0.196 & -0.197 \\
\hline & $(0.021)^{* *}$ & $(0.021)^{* *}$ & $(0.022)^{* *}$ & $(0.022)^{* *}$ & $(0.022)^{* *}$ \\
\hline TARIFFS & 0.019 * & 0.020 * & $0.020 *$ & 0.020 & 0.020 \\
\hline \multirow[t]{2}{*}{ CHNGE_TARIFFS } & 0.059 & $\begin{array}{r}(0.003) \\
0.058\end{array}$ & 0.064 & 0.064 & $\begin{array}{l}(0.003)^{n+n} \\
0.064\end{array}$ \\
\hline & $(0.011)^{* *}$ & $(0.011)^{* *}$ & $(0.011)^{* *}$ & $(0.011)^{* *}$ & $(0.011)^{* *}$ \\
\hline \multirow{2}{*}{ REP_SENATE } & & -0.154 & -0.295 & -0.295 & -0.299 \\
\hline & & $(0.057)^{* *}$ & $(0.080)^{* *}$ & $(0.080)^{* *}$ & $(0.080)^{* *}$ \\
\hline \multirow[t]{2}{*}{ REPPRES*REP_SENATE } & & 0.482 & 0.774 & 0.772 & 0.775 \\
\hline & & $(0.063)^{* \pi+}$ & $(0.095)^{* *}$ & $(0.095)^{* *}$ & $(0.095)^{* *}$ \\
\hline ELYEAR_SENTR & & $\begin{array}{c}0.006 \\
(0.028)\end{array}$ & -0.012 & -0.019 & -0.019 \\
\hline \multirow{2}{*}{ REP_HOUSE } & & $(0.028)$ & $\begin{array}{l}(0.029) \\
-0.138\end{array}$ & $(0.031)$ & $(0.031)$ \\
\hline & & & $(0.104)$ & $(0.105)$ & $(0.105)$ \\
\hline \multirow[t]{2}{*}{ REPPRES*REP_HOUSE } & & & -0.382 & -0.334 & -0.341 \\
\hline & & & $(0.098)^{* *}$ & $(0.098)^{* *}$ & $(0.099)^{* *}$ \\
\hline \multirow[t]{2}{*}{ REP_GOVRNR } & & & & 0.110 & 0.115 \\
\hline & & & & $(0.055)^{*}$ & $(0.055)^{*}$ \\
\hline \multirow[t]{2}{*}{ OTHER_GOVRNR } & & & & 0.082 & 0.203 \\
\hline & & & & $(0.172)$ & $(0.208)$ \\
\hline REPPRES*REP_GOVRNR & & & & $(0.061)^{-0.200}$ & $\begin{array}{c}-0.205 \\
(0.061)^{* *}\end{array}$ \\
\hline \multirow[t]{2}{*}{ REPPRES*OTHER_GOVRNR } & & & & -0.236 & -0.372 \\
\hline & & & & $(0.215)$ & $(0.251)$ \\
\hline ELYEAR_GUVNR & & & & 0.028 & 0.029 \\
\hline ALWAYSDEM & & & & $(0.031)$ & $\begin{array}{l}(0.031) \\
-0.505\end{array}$ \\
\hline & & & & & $(0.287)^{+}$ \\
\hline ALWAYSREP & & & & & -0.469 \\
\hline REPPRFS*ALWAYSDEM & & & & & $(0.518)$ \\
\hline & & & & & $(0.280)$ \\
\hline REPPRES*ALWAYSREP & & & & & 0.190 \\
\hline & & & & & $(0.112)^{+}$ \\
\hline _cons & -198.080 & -209.957 & -257.596 & -253.245 & -253.700 \\
\hline & $(6.135)^{* *}$ & $(6.530)^{* *}$ & $(12.588)^{* *}$ & $(12.745)^{* *}$ & $(12.758)^{* *}$ \\
\hline$N$ & 35634 & 35634 & 35634 & 35634 & 35634 \\
\hline state \& ind. FE & yes & yes & yes & yes & yes \\
\hline
\end{tabular}

Notes: This table reports estimates obtained after introducing additional political covariates. Column (1) reproduces our main results with only the main political variables and state and industry fixed effects. Column (2) introduces political variables for Senate. Column (3) introduces political variables for the House of Representatives. Column (4) introduces additional political variables for Governor. Column (5) controls for states that always voted for the same party. Standard errors in parentheses ${ }^{+} p<0.10$, $^{*}$ $p<.05,{ }^{* *} p<.01$. See text for further details. 
TABle 6. Marginal Effects: Congress Composition \& Governor Affiliation

\begin{tabular}{|c|c|c|c|c|c|}
\hline $\begin{array}{l}\text { A. Marginal Effects State } \\
\text { (REPSTATE changes from } 0 \text { to } 1 \text { ) }\end{array}$ & $(1)$ & $\overline{(2)}$ & $(3)$ & $(4)$ & $\overline{(5)}$ \\
\hline at $\mathrm{REPPRES}=0$ & $\begin{array}{c}0.022 \\
(0.011)^{*}\end{array}$ & $\begin{array}{c}0.021 \\
(0.011)^{+}\end{array}$ & $\begin{array}{c}0.028 \\
(0.011)^{*}\end{array}$ & $\begin{array}{c}0.028 \\
(0.011)^{*}\end{array}$ & $\begin{array}{c}0.036 \\
(0.012)^{* *}\end{array}$ \\
\hline at $\mathrm{REPPRES}=1$ & $\begin{array}{c}0.047 \\
(0.009)^{* *}\end{array}$ & $\begin{array}{c}0.061 \\
(0.009)^{* *}\end{array}$ & $\begin{array}{c}0.053 \\
(0.009)^{* *}\end{array}$ & $\begin{array}{c}0.056 \\
(0.009)^{* *}\end{array}$ & $\begin{array}{c}0.056 \\
(0.009)^{* *}\end{array}$ \\
\hline
\end{tabular}

B. Marginal Effects Senate

(REP_SENATE changes from 0 to 1 )

\begin{tabular}{lcccc}
\hline at $\mathrm{REPPRES}=0$ & -0.030 & -0.056 & -0.057 & -0.057 \\
& $(0.011)^{* *}$ & $(0.015)^{* *}$ & $(0.015)^{* *}$ & $(0.015)^{* *}$ \\
at REPPRES=1 & 0.067 & 0.099 & 0.098 & 0.098 \\
& $(0.007)^{* *}$ & $(0.010)^{* *}$ & $(0.010)^{* *}$ & $(0.010)^{* *}$ \\
\hline \hline
\end{tabular}

C. Marginal Effects House

(REP_HOUSE changes from 0 to 1 )

\begin{tabular}{lccc}
\hline at $\mathrm{REPPRES}=0$ & -0.026 & -0.028 & -0.027 \\
& $(0.019)$ & $(0.020)$ & $(0.020)$ \\
at $\mathrm{REPPRES}=1$ & -0.100 & -0.092 & -0.093 \\
& $(0.020)^{* *}$ & $(0.021)^{* *}$ & $(0.021)^{* *}$ \\
\hline
\end{tabular}

D. Marginal Effects Republican Governor

(REP_GOVRNR changes from 0 to 1 )

\begin{tabular}{|c|c|c|}
\hline \multirow[t]{2}{*}{ at $\mathrm{REPPRES}=0$} & 0.021 & 0.022 \\
\hline & $(0.011)^{*}$ & $(0.011)^{*}$ \\
\hline \multirow[t]{2}{*}{ at $\mathrm{REPPRES}=1$} & -0.018 & -0.018 \\
\hline & $(0.006)^{* *}$ & $(0.006)^{* *}$ \\
\hline
\end{tabular}

E. Marginal Effects 'Other' Governor

(OTHER_GOVRNR changes from 0 to 1 )

\begin{tabular}{lcc}
\hline \hline at $\mathrm{REPPRES}=0$ & 0.016 & 0.039 \\
& $(0.033)$ & $(0.039)$ \\
at $\mathrm{REPPRES}=1$ & -0.031 & -0.034 \\
& $(0.033)$ & $(0.033)$ \\
\hline
\end{tabular}

$\begin{array}{llllll}N & 35634 & 35634 & 35634 & 35634 & 35634\end{array}$

Notes: This table reports average marginal effects constructed from the estimates in Table 5. The results in all panels are by presidential affiliation. Panel A reports the effects of changes in state affiliation, Panel B the effects of changes in Senate affiliation, and Panel C the effects of changes in House affiliation. Panels D and E display the effects of changes in Governor affiliation. The column labels refer to those in Table 5. Standard errors in parentheses. ${ }^{+} p<0.10,{ }^{*} p<.05,{ }^{* *} p<.01$ 
Figure 1. Frequency and Success Rate of TAA Petitions by Census Division
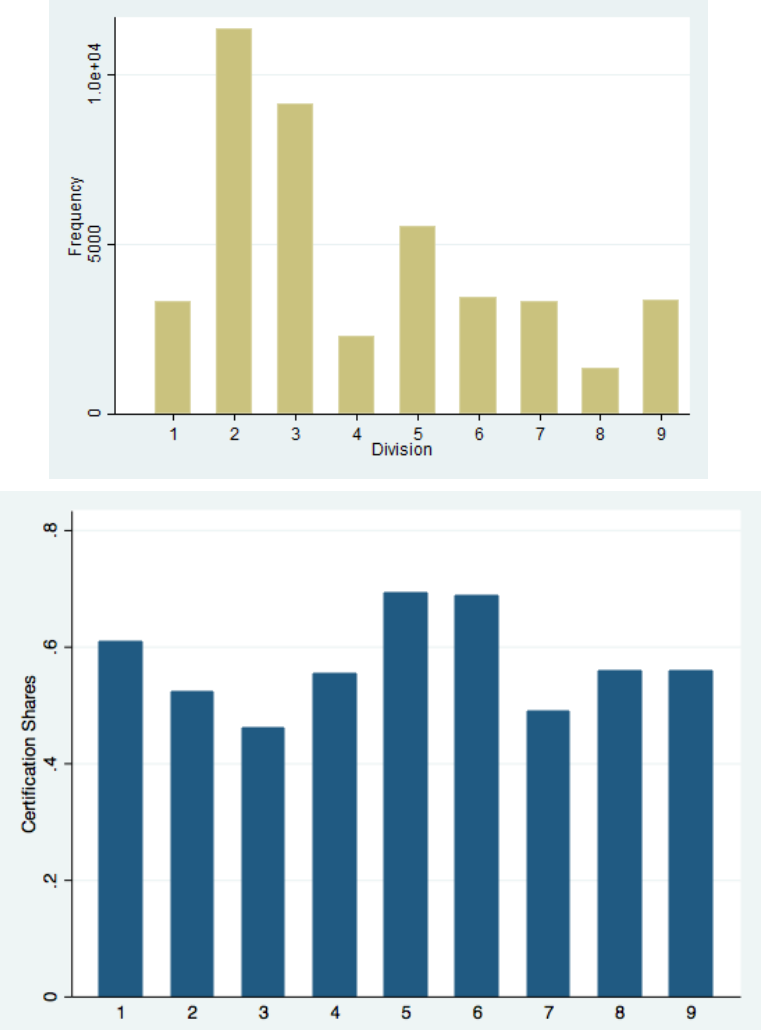

Div. 1: New England: CT, ME, MA, NH, RI, VT; Div 2: Middle Atlantic: NJ, NY, PA; Div. 3: East North Central: IN, IL, MI, OH, WI; Div. 4: West North Central: IA, KS, MN, MO, NE, ND, SD; Div. 5: South Atlantic: DE, DC, FL, GA, MD, NC, SC, VA, WV; Div. 6: East South Central: AL, KY, MS, TN; Div. 7: West South Central: AR, LA, OK, TX; Div. 8: Mountain: AZ, CO, ID, NM, MT, UT, NV, WY; Div. 9: Pacific: AK, CA, HI, OR, WA 
Figure 2. Frequency and Success Rate of TAA Petitions by SIC-2 Industry
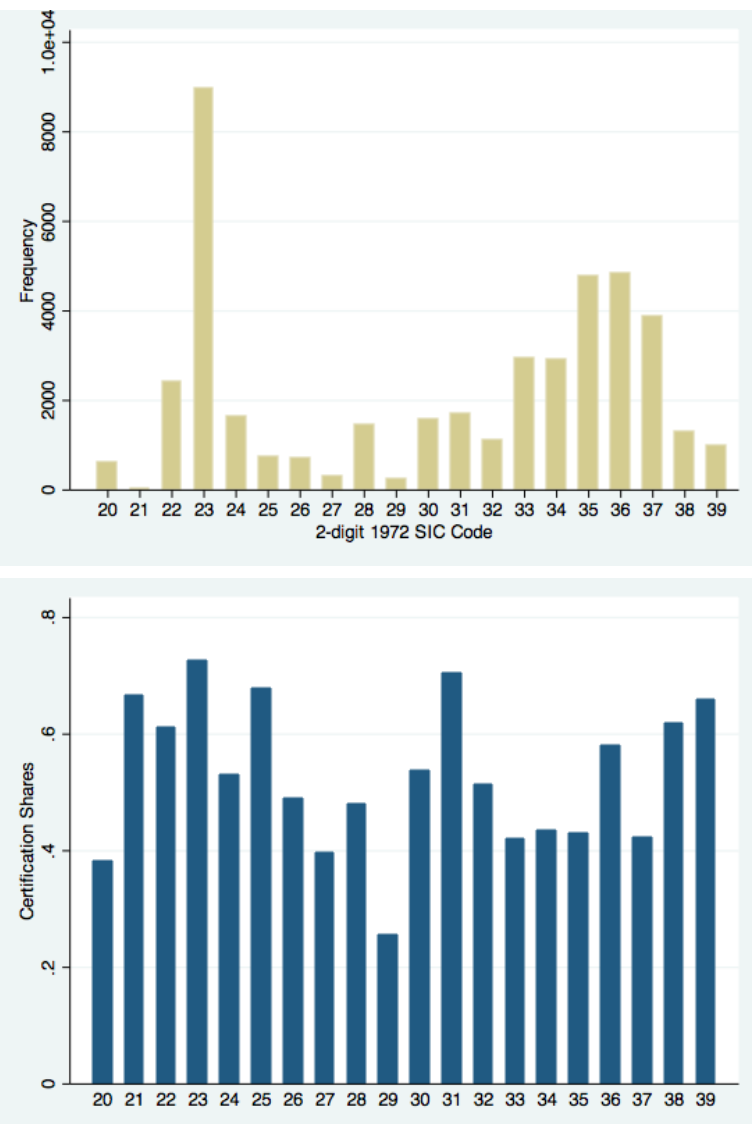

20: Food \& Kindred Products, 21: Tobacco Products, 22: Textile Mill Products, 23: Apparel \& Other Textile Products, 24: Lumber \& Wood Products, 25: Furniture \& Fixtures, 26: Paper \& Allied Products, 27: Printing \& Publishing, 28: Chemical \& Allied Products, 29: Petroleum \& Coal Products, 30: Rubber \& Miscellaneous Plastics Products, 31: Leather \& Leather Products, 32: Stone, Clay, \& Glass Products, 33: Primary Metal Industries, 34: Fabricated Metal Products, 35: Industrial Machinery \& Equipment, 36: Electronic \& Other Electric Equipment, 37: Transportation Equipment, 38: Instruments \& Related Products, 39: Miscellaneous Manufacturing Industries 
Figure 3. Average Certification Rates (SAMEPOL)
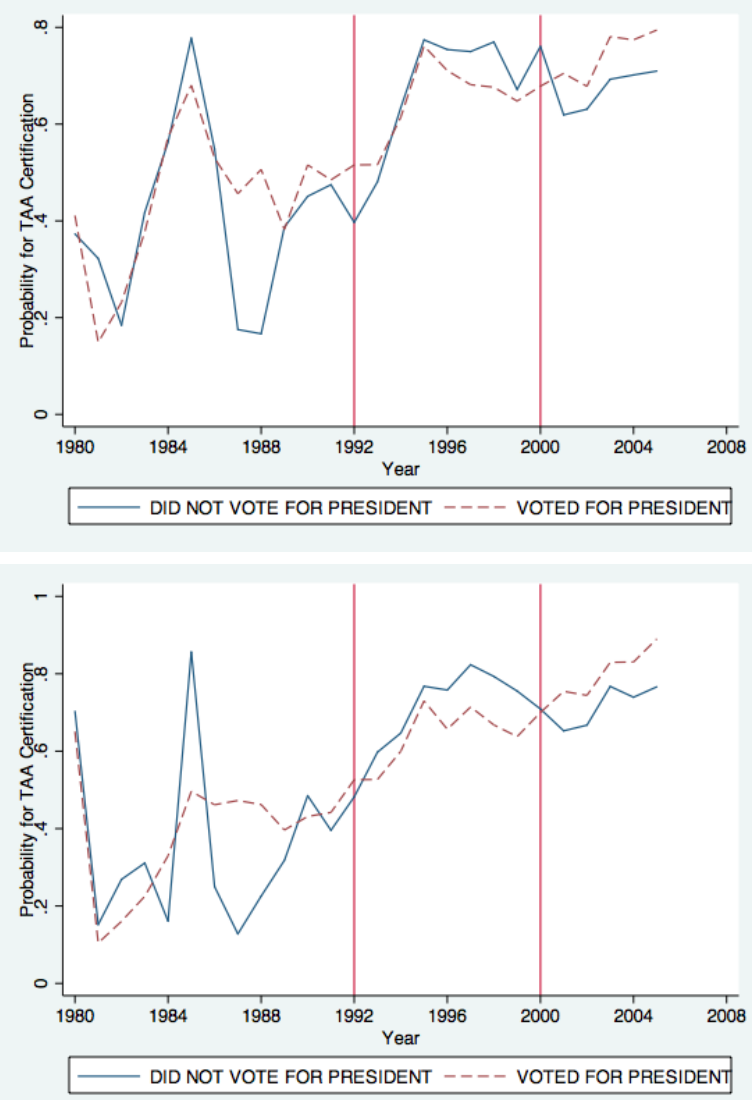

Notes: This figure depicts the evolution of average certification rates depending on whether in the last election a given state voted for the candidate who won the Presidential election or for the losing candidate. The top panel of the figure graphs simple average data, while the bottom panel uses a weighting procedure which is described in the main text. 
Figure 4. Average Certification Rates (REP vs. DEM)
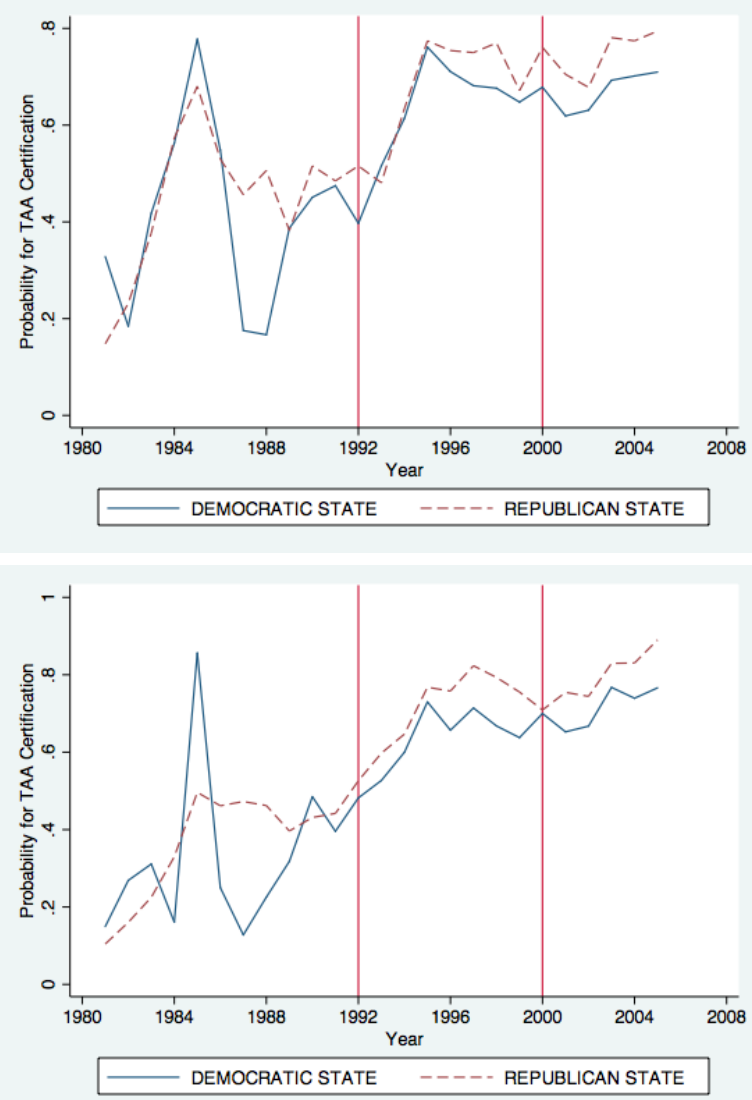

Notes: This figure depicts the evolution of average certification rates depending on whether in the last election a given state voted for the Republicans or for the Democrats. The top panel of the figure graphs simple average data, while the bottom panel uses a weighting procedure which is described in the main text. 
Figure 5. Simple Average Certification Rates (ALWAYS_SAME)
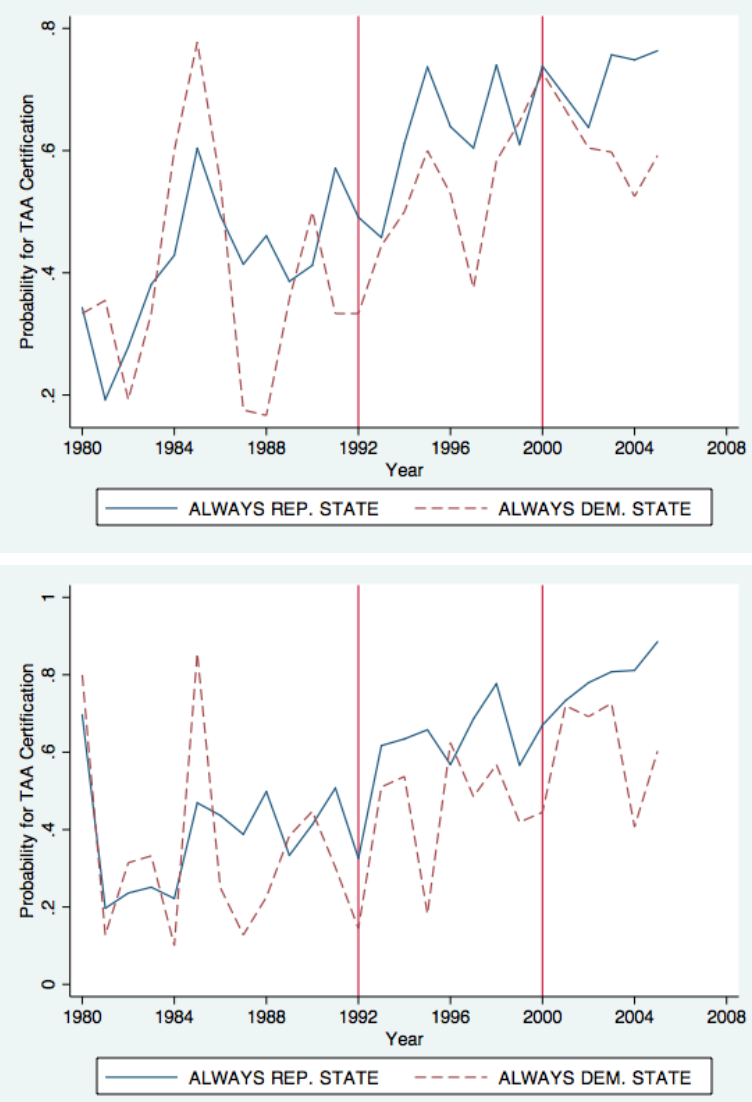

Notes: This figure depicts the evolution of average certification rates depending on whether a given state always voted for the Republicans or for the Democrats. The top panel of the figure graphs simple average data, while the bottom panel uses a weighting procedure as described in the main text. 


\section{Appendix A: Summary Statistics}

This appendix includes the following tables: summary statistics for our dependent variable (Certified) by 2-digit SIC and by Division (Table 7), by 2-digit SIC and by electoral period (Table 8), and by Division and by electoral period (Table 9). Tables (10) to (12) reproduce Tables (7) to (9), but for another key variable $\left(E S T \_W R K R S\right)$. The complete data set is available upon request from the authors.

TABle 7. Summary Statistics: Certified

\begin{tabular}{|c|c|c|c|c|c|c|c|c|c|}
\hline SIC2 & Div1 & Div2 & Div3 & Div4 & Div5 & Div6 & Div7 & Div8 & Div9 \\
\hline \multirow[t]{2}{*}{20} & .55 & .294 & .333 & .286 & .342 & .615 & .359 & .4 & .5 \\
\hline & $(.504)$ & $(.457)$ & $(.474)$ & $(.457)$ & $(.481)$ & $(.506)$ & $(.486)$ & $(.5)$ & $(.502)$ \\
\hline \multirow[t]{2}{*}{21} & 0 & .375 & 0 & 0 & .75 & 1 & 0 & 1 & 0 \\
\hline & (.) & $(.518)$ & (.) & (.) & $(.444)$ & (.) & (.) & (.) & (.) \\
\hline \multirow[t]{2}{*}{22} & .525 & .516 & .5 & .667 & .679 & .637 & .725 & .375 & .755 \\
\hline & $(.5)$ & $(.5)$ & $(.504)$ & $(.479)$ & $(.467)$ & $(.482)$ & $(.452)$ & $(.518)$ & $(.434)$ \\
\hline \multirow[t]{2}{*}{23} & .756 & .6 & .695 & .76 & .857 & .841 & .825 & .944 & .833 \\
\hline & $(.43)$ & $(.49)$ & $(.461)$ & $(.428)$ & $(.35)$ & $(.366)$ & $(.38)$ & $(.23)$ & $(.374)$ \\
\hline \multirow[t]{2}{*}{24} & .681 & .625 & .491 & .8 & .698 & .718 & .55 & .601 & .468 \\
\hline & $(.468)$ & $(.489)$ & $(.502)$ & $(.41)$ & $(.462)$ & $(.456)$ & $(.504)$ & $(.491)$ & $(.499)$ \\
\hline \multirow[t]{2}{*}{25} & .714 & .524 & .597 & .586 & .833 & .596 & .652 & .9 & .676 \\
\hline & $(.46)$ & $(.501)$ & $(.493)$ & $(.501)$ & $(.373)$ & $(.494)$ & $(.482)$ & $(.316)$ & $(.475)$ \\
\hline \multirow[t]{2}{*}{26} & .482 & .428 & .518 & .6 & .429 & .615 & .463 & .556 & .478 \\
\hline & $(.502)$ & $(.496)$ & $(.501)$ & $(.497)$ & $(.499)$ & $(.493)$ & $(.505)$ & $(.527)$ & $(.503)$ \\
\hline \multirow[t]{2}{*}{27} & .375 & .337 & .491 & .412 & .439 & .35 & .167 & .4 & .75 \\
\hline & $(.492)$ & $(.475)$ & $(.505)$ & $(.507)$ & $(.502)$ & $(.489)$ & $(.383)$ & $(.548)$ & $(.452)$ \\
\hline \multirow[t]{2}{*}{28} & .648 & .425 & .466 & .679 & .51 & .358 & .38 & .644 & .627 \\
\hline & $(.482)$ & $(.495)$ & $(.5)$ & $(.47)$ & $(.501)$ & $(.482)$ & $(.487)$ & $(.482)$ & $(.487)$ \\
\hline \multirow[t]{2}{*}{29} & .333 & .219 & 289 & .167 & .278 & .313 & 217 & .3 & .364 \\
\hline & $(.577)$ & $(.42)$ & $(.458)$ & $(.389)$ & $(.461)$ & $(.479)$ & $(.415)$ & $(.466)$ & $(.505)$ \\
\hline \multirow[t]{2}{*}{30} & .622 & .538 & .415 & .515 & .633 & .692 & .519 & .471 & .671 \\
\hline & $(.486)$ & $(.499)$ & $(.493)$ & $(.502)$ & $(.484)$ & $(.463)$ & $(.502)$ & $(.514)$ & $(.473)$ \\
\hline \multirow[t]{2}{*}{31} & .641 & .692 & .733 & .679 & .879 & .711 & .716 & .917 & .87 \\
\hline & $(.48)$ & $(.462)$ & $(.444)$ & $(.468)$ & $(.327)$ & $(.455)$ & $(.453)$ & $(.289)$ & $(.344)$ \\
\hline \multirow[t]{2}{*}{32} & .418 & .474 & .442 & .476 & .647 & .66 & .558 & .458 & .754 \\
\hline & $(.498)$ & $(.5)$ & $(.497)$ & $(.505)$ & $(.48)$ & $(.479)$ & $(.499)$ & $(.509)$ & $(.434)$ \\
\hline \multirow[t]{2}{*}{33} & .38 & .433 & .396 & .38 & .452 & .413 & .413 & .46 & .486 \\
\hline & $(.487)$ & $(.496)$ & $(.489)$ & $(.488)$ & $(.499)$ & $(.494)$ & $(.494)$ & $(.5)$ & $(.501)$ \\
\hline \multirow[t]{2}{*}{34} & .652 & .434 & .368 & .389 & .459 & .51 & .446 & .355 & .576 \\
\hline & $(.478)$ & $(.496)$ & $(.483)$ & $(.489)$ & $(.5)$ & $(.502)$ & $(.498)$ & $(.482)$ & $(.496)$ \\
\hline \multirow[t]{2}{*}{35} & .598 & .459 & .432 & .42 & .53 & .475 & .18 & .469 & .57 \\
\hline & $(.491)$ & $(.499)$ & $(.496)$ & $(.494)$ & $(.5)$ & $(.501)$ & $(.385)$ & $(.5)$ & $(.496)$ \\
\hline \multirow[t]{2}{*}{36} & .587 & .517 & .576 & .588 & .684 & .669 & .576 & .545 & .564 \\
\hline & $(.493)$ & $(.5)$ & $(.494)$ & $(.493)$ & $(.466)$ & $(.471)$ & $(.495)$ & $(.499)$ & $(.496)$ \\
\hline \multirow[t]{2}{*}{37} & .397 & .413 & .41 & .433 & .437 & .523 & .398 & .543 & .412 \\
\hline & $(.491)$ & $(.493)$ & $(.492)$ & $(.497)$ & $(.497)$ & $(.5)$ & $(.49)$ & $(.501)$ & $(.493)$ \\
\hline \multirow[t]{2}{*}{38} & .64 & .513 & .663 & .594 & .787 & .8 & .595 & .573 & .648 \\
\hline & $(.482)$ & $(.5)$ & $(.474)$ & $(.495)$ & $(.411)$ & $(.404)$ & $(.493)$ & $(.498)$ & $(.479)$ \\
\hline \multirow[t]{2}{*}{39} & .702 & .595 & .582 & .648 & .711 & .74 & .765 & .92 & .747 \\
\hline & $(.459)$ & $(.492)$ & $(.495)$ & $(.482)$ & $(.456)$ & $(.443)$ & $(.428)$ & $(.277)$ & $(.438)$ \\
\hline
\end{tabular}

Notes: This table reports average values for our dependent variable (Certified) by 2-digit SIC sector and by division. Standard deviations in parentheses. 
TABLE 8. Summary Statistics: Certified

\begin{tabular}{|c|c|c|c|c|c|c|c|c|}
\hline SIC2 & Carter & Reagan1 & Reagan2 & BushSr & Clinton1 & Clinton2 & BushJr1 & BushJr2 \\
\hline \multirow[t]{2}{*}{20} & .143 & .158 & 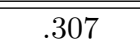 & 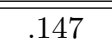 & $\bar{~} .447$ & .411 & 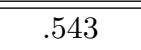 & 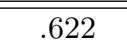 \\
\hline & $(.359)$ & $(.368)$ & $(.464)$ & $(.356)$ & $(.5)$ & $(.495)$ & $(.5)$ & $(.492)$ \\
\hline \multirow[t]{2}{*}{21} & 0 & 0 & .333 & 0 & 0 & 1 & .714 & .875 \\
\hline & (.) & (.) & $(.516)$ & (.) & (.) & (.) & (.469) & $(.354)$ \\
\hline \multirow[t]{2}{*}{22} & .35 & .222 & .339 & .358 & .685 & .644 & .792 & .818 \\
\hline & $(.479)$ & $(.417)$ & $(.474)$ & $(.481)$ & $(.466)$ & $(.479)$ & $(.406)$ & $(.386)$ \\
\hline \multirow[t]{2}{*}{23} & .506 & .326 & .611 & .72 & .886 & .922 & .907 & .865 \\
\hline & $(.5)$ & (.469) & $(.488)$ & $(.449)$ & $(.318)$ & $(.268)$ & $(.291)$ & $(.342)$ \\
\hline \multirow[t]{2}{*}{24} & .378 & .287 & .462 & .389 & .687 & .549 & .658 & .684 \\
\hline & $(.487)$ & $(.455)$ & $(.499)$ & $(.488)$ & $(.465)$ & (.499) & $(.475)$ & $(.468)$ \\
\hline \multirow[t]{2}{*}{25} & .333 & .529 & .7 & .444 & .508 & .565 & .74 & .888 \\
\hline & $(.577)$ & $(.507)$ & (.462) & $(.5)$ & $(.504)$ & $(.499)$ & (.44) & $(.317)$ \\
\hline \multirow[t]{2}{*}{26} & . 182 & 176 & .301 & 271 & .382 & .566 & .607 & .517 \\
\hline & $(.405)$ & (.393) & $(.462)$ & $(.449)$ & (.488) & (.498) & (.489) & $(.504)$ \\
\hline \multirow[t]{2}{*}{27} & 0 & .5 & .379 & . 167 & .265 & . 404 & .49 & .571 \\
\hline & (0) & $(.707)$ & (.494) & $(.379)$ & $(.446)$ & $(.495)$ & $(.502)$ & $(.504)$ \\
\hline \multirow[t]{2}{*}{28} & 0 & .276 & .446 & .361 & .401 & .58 & .668 & .625 \\
\hline & (0) & (.449) & (.498) & $(.482)$ & $(.492)$ & (.495) & $(.472)$ & $(.487)$ \\
\hline \multirow[t]{2}{*}{29} & 0 & .053 & .226 & .423 & .407 & .111 & .333 & .667 \\
\hline & (0) & $(.229)$ & $(.42)$ & $(.504)$ & $(.496)$ & $(.318)$ & $(.492)$ & $(.577)$ \\
\hline \multirow[t]{2}{*}{30} & .277 & .116 & .681 & .491 & .533 & .596 & .616 & .75 \\
\hline & $(.45)$ & $(.321)$ & $(.467)$ & $(.501)$ & $(.501)$ & $(.492)$ & $(.487)$ & $(.435)$ \\
\hline \multirow[t]{2}{*}{31} & .472 & .47 & .825 & .586 & .796 & .876 & .75 & .783 \\
\hline & $(.502)$ & $(.5)$ & $(.38)$ & $(.494)$ & (.404) & (.33) & $(.435)$ & $(.422)$ \\
\hline \multirow[t]{2}{*}{32} & .22 & 257 & .503 & .236 & .653 & .661 & .711 & .742 \\
\hline & $(.419)$ & (.438) & $(.501)$ & $(.427)$ & (.478) & $(.476)$ & $(.454)$ & $(.445)$ \\
\hline \multirow[t]{2}{*}{33} & .075 & .319 & .356 & .285 & .485 & .533 & .676 & .763 \\
\hline & $(.264)$ & $(.466)$ & $(.479)$ & $(.452)$ & $(.501)$ & $(.5)$ & $(.468)$ & $(.429)$ \\
\hline \multirow[t]{2}{*}{34} & .237 & . 167 & .44 & .349 & .406 & .549 & .619 & .656 \\
\hline & $(.427)$ & $(.373)$ & (.497) & $(.478)$ & (.493) & (.499) & $(.486)$ & $(.477)$ \\
\hline \multirow[t]{2}{*}{35} & .181 & .219 & .418 & .305 & .545 & . .441 & .573 & .652 \\
\hline & $(.386)$ & $(.414)$ & (.493) & $(.461)$ & (.499) & $(.497)$ & (.495) & $(.478)$ \\
\hline \multirow[t]{2}{*}{36} & .423 & .326 & .498 & .479 & .636 & .672 & .712 & .764 \\
\hline & $(.496)$ & $(.47)$ & $(.5)$ & $(.5)$ & $(.482)$ & $(.47)$ & $(.453)$ & $(.425)$ \\
\hline \multirow[t]{2}{*}{37} & . 489 & .184 & .498 & .349 & .467 & .535 & .587 & .752 \\
\hline & $(.5)$ & $(.388)$ & $(.5)$ & $(.477)$ & $(.5)$ & $(.5)$ & $(.493)$ & $(.434)$ \\
\hline \multirow[t]{2}{*}{38} & .48 & .41 & .54 & . 401 & .6 & .693 & .721 & .818 \\
\hline & $(.51)$ & $(.495)$ & (.499) & $(.492)$ & $(.492)$ & $(.463)$ & (.449) & $(.387)$ \\
\hline \multirow[t]{2}{*}{39} & .419 & .411 & .595 & .602 & .75 & .747 & .776 & .86 \\
\hline & $(.499)$ & $(.494)$ & $(.492)$ & $(.492)$ & $(.435)$ & $(.436)$ & (.418) & $(.351)$ \\
\hline
\end{tabular}

Notes: This table reports average values for our dependent variable (Certified) by 2-digit SIC sector and by electoral period. Standard deviations in parentheses. 
TABLE 9. Summary Statistics: Certified

\begin{tabular}{|c|c|c|c|c|c|c|c|c|}
\hline Div & Carter & Reagan1 & Reagan2 & BushSr & Clinton1 & Clinton2 & BushJr1 & BushJr2 \\
\hline \multirow[t]{2}{*}{$\bar{~} 1$} & .456 & .336 & .651 & .47 & .699 & .728 & .708 & .705 \\
\hline & $(.499)$ & $(.473)$ & $(.477)$ & $(.5)$ & $(.46)$ & $(.446)$ & $(.455)$ & $(.457)$ \\
\hline \multirow[t]{2}{*}{2} & 431 & .309 & 482 & 439 & .658 & .676 & .667 & .718 \\
\hline & $(.496)$ & $(.462)$ & $(.5)$ & $(.496)$ & $(.474)$ & $(.468)$ & $(.471)$ & $(.451)$ \\
\hline \multirow[t]{2}{*}{3} & .363 & . 172 & .525 & .393 & .555 & .582 & .642 & .71 \\
\hline & $(.481)$ & $(.378)$ & (.499) & $(.489)$ & $(.497)$ & $(.494)$ & $(.479)$ & $(.455)$ \\
\hline \multirow[t]{2}{*}{4} & .323 & .283 & .543 & 488 & .653 & .668 & .65 & .733 \\
\hline & $(.469)$ & $(.451)$ & (.499) & $(.501)$ & $(.477)$ & $(.472)$ & $(.477)$ & $(.445)$ \\
\hline \multirow[t]{2}{*}{5} & .37 & .367 & .569 & .71 & .763 & .796 & .776 & .802 \\
\hline & $(.484)$ & $(.482)$ & (.496) & $(.454)$ & $(.426)$ & $(.403)$ & $(.417)$ & (.399) \\
\hline \multirow[t]{2}{*}{6} & .326 & .273 & .694 & .642 & .79 & .816 & .784 & .804 \\
\hline & $(.47)$ & $(.446)$ & $(.461)$ & $(.48)$ & $(.407)$ & $(.388)$ & $(.412)$ & (.398) \\
\hline \multirow[t]{2}{*}{7} & .446 & .371 & .3 & .429 & .551 & .637 & .683 & .803 \\
\hline & $(.5)$ & $(.484)$ & $(.458)$ & $(.496)$ & $(.498)$ & $(.481)$ & $(.466)$ & $(.399)$ \\
\hline 8 & .459 & .333 & .429 & .517 & .77 & $\begin{array}{l}.605 \\
(49)\end{array}$ & .648 & .738 \\
\hline \multirow[t]{2}{*}{9} & $\begin{array}{c}(.505) \\
.395\end{array}$ & $\begin{array}{c}(.473) \\
.333\end{array}$ & $\begin{array}{c}(.496) \\
.502\end{array}$ & $\begin{array}{c}(.501) \\
.442\end{array}$ & $\begin{array}{l}(.422) \\
.574\end{array}$ & $\begin{array}{l}.49) \\
.601\end{array}$ & $\begin{array}{c}(.48) \\
.695\end{array}$ & $\begin{array}{l}(.443) \\
.747\end{array}$ \\
\hline & (.49) & $(.472)$ & $(.5)$ & $(.497)$ & (.495) & $(.49)$ & (.461) & $(.436)$ \\
\hline
\end{tabular}

Notes: This table reports average values for our dependent variable (Certified) by division and by electoral period. Standard deviations in parentheses. 
TABLE 10. Summary Statistics: EST_WRKRS

\begin{tabular}{|c|c|c|c|c|c|c|c|c|c|}
\hline SIC2 & Div1 & Div2 & Div3 & Div4 & Div5 & Div6 & Div7 & Div8 & Div9 \\
\hline \multirow[t]{2}{*}{20} & 90 & 118 & 211 & 131 & 186 & 81 & 123 & 158 & 174 \\
\hline & (115) & (139) & $(253)$ & $(143)$ & $(166)$ & (93) & (139) & $(120)$ & (191) \\
\hline \multirow[t]{2}{*}{21} & 0 & 128 & 0 & 0 & 214 & 148 & 0 & 116 & 0 \\
\hline & (.) & $(170)$ & (.) & (.) & $(441)$ & (.) & (.) & (.) & (.) \\
\hline \multirow[t]{2}{*}{22} & 78 & 54 & 87 & 53 & 133 & 122 & 170 & 62 & 49 \\
\hline & $(86)$ & $(72)$ & (96) & (64) & $(167)$ & $(157)$ & $(242)$ & (119) & (68) \\
\hline \multirow[t]{2}{*}{23} & 64 & 46 & 86 & 77 & 115 & 140 & 137 & 87 & 98 \\
\hline & $(125)$ & (58) & $(102)$ & (85) & $(130)$ & (168) & (209) & (109) & (181) \\
\hline \multirow[t]{2}{*}{24} & 40 & 59 & 77 & 47 & 58 & 80 & 82 & 90 & 55 \\
\hline & $(42)$ & $(72)$ & (97) & (74) & (61) & (106) & (87) & (137) & $(80)$ \\
\hline \multirow[t]{2}{*}{25} & 77 & 108 & 132 & 87 & 108 & 134 & 108 & 116 & 153 \\
\hline & $(80)$ & $(150)$ & $(155)$ & $(126)$ & (134) & (131) & $(115)$ & $(130)$ & $(277)$ \\
\hline \multirow[t]{2}{*}{26} & 103 & 106 & 95 & 132 & 138 & 204 & 107 & 37 & 127 \\
\hline & (114) & $(115)$ & (91) & $(120)$ & $(231)$ & $(175)$ & $(125)$ & $(35)$ & $(122)$ \\
\hline \multirow[t]{2}{*}{27} & 98 & 76 & 155 & 107 & 107 & 91 & 68 & 90 & 47 \\
\hline & (103) & $(86)$ & $(204)$ & (138) & (126) & (109) & $(83)$ & (84) & (35) \\
\hline \multirow[t]{2}{*}{28} & 83 & 104 & 65 & 52 & 105 & 146 & 67 & 93 & 71 \\
\hline & $(172)$ & $(205)$ & $(105)$ & (78) & (154) & (196) & (168) & $(254)$ & (107) \\
\hline \multirow[t]{2}{*}{29} & 110 & 98 & 71 & 45 & 85 & 105 & 139 & 40 & 144 \\
\hline & (85) & $(120)$ & (91) & (43) & (116) & $(86)$ & (299) & $(42)$ & $(228)$ \\
\hline \multirow[t]{2}{*}{30} & 78 & 90 & 125 & 113 & 207 & 155 & 182 & 144 & 93 \\
\hline & (84) & $(147)$ & $(201)$ & $(226)$ & $(299)$ & $(225)$ & $(305)$ & $(228)$ & (181) \\
\hline \multirow[t]{2}{*}{31} & 70 & 63 & 78 & 106 & 124 & 74 & 99 & 60 & 108 \\
\hline & (83) & (91) & (92) & $(111)$ & $(137)$ & $(80)$ & (106) & $(50)$ & $(267)$ \\
\hline \multirow[t]{2}{*}{32} & 127 & 101 & 101 & 76 & 127 & 102 & 83 & 44 & 74 \\
\hline & $(200)$ & $(243)$ & (118) & (74) & $(155)$ & $(152)$ & $(96)$ & (49) & $(122)$ \\
\hline \multirow[t]{2}{*}{33} & 175 & 142 & 169 & 134 & 176 & 172 & 189 & 217 & 105 \\
\hline & $(524)$ & $(285)$ & $(356)$ & $(177)$ & $(321)$ & $(313)$ & $(345)$ & $(308)$ & (139) \\
\hline \multirow[t]{2}{*}{34} & 74 & 92 & 107 & 80 & 117 & 98 & 106 & 94 & 112 \\
\hline & (100) & $(164)$ & $(153)$ & (95) & (119) & (108) & (138) & (132) & (183) \\
\hline \multirow[t]{2}{*}{35} & 118 & 99 & 111 & 136 & 104 & 160 & 133 & 128 & 109 \\
\hline & $(229)$ & $(172)$ & $(174)$ & $(195)$ & (139) & (184) & $(557)$ & $(233)$ & (158) \\
\hline \multirow[t]{2}{*}{36} & 101 & 122 & 136 & 108 & 159 & 150 & 182 & 137 & 114 \\
\hline & $(155)$ & $(209)$ & $(224)$ & $(132)$ & $(306)$ & (192) & $(364)$ & $(226)$ & $(239)$ \\
\hline \multirow[t]{2}{*}{37} & 361 & 293 & 446 & 399 & 247 & 230 & 282 & 120 & 572 \\
\hline & $(827)$ & $(818)$ & (1168) & $(1045)$ & (699) & $(458)$ & $(869)$ & $(379)$ & $(1808)$ \\
\hline \multirow[t]{2}{*}{38} & 103 & 108 & 134 & 98 & 86 & 72 & 128 & 91 & 109 \\
\hline & $(117)$ & $(243)$ & $(274)$ & (133) & (113) & $(71)$ & $(332)$ & (126) & $(140)$ \\
\hline \multirow[t]{2}{*}{39} & 69 & 96 & 64 & 191 & 74 & 184 & 100 & 54 & 82 \\
\hline & $(81)$ & $(209)$ & (96) & $(755)$ & $(170)$ & $(558)$ & (183) & (54) & (106) \\
\hline
\end{tabular}

Notes: This table reports the average estimated number of workers $\left(E S T_{-} W R K R S\right)$ to be laid off due to trade by 2-digit SIC sector and by division. Standard deviations in parentheses. 
TABLE 11. Summary Statistics: EST_WRKRS

\begin{tabular}{|c|c|c|c|c|c|c|c|c|}
\hline $\begin{array}{l}\text { SIC2 } \\
\end{array}$ & Carter & Reagan1 & Reagan2 & BushSr & Clinton1 & Clinton2 & BushJr1 & BushJr2 \\
\hline 20 & $\begin{array}{c}126 \\
(253)\end{array}$ & $\begin{array}{c}132 \\
(132)\end{array}$ & $\begin{array}{c}170 \\
(185)\end{array}$ & $\begin{array}{c}146 \\
(151)\end{array}$ & $\begin{array}{c}136 \\
(170)\end{array}$ & $\begin{array}{c}178 \\
(214)\end{array}$ & $\begin{array}{c}158 \\
(187)\end{array}$ & $\begin{array}{c}113 \\
(115)\end{array}$ \\
\hline 21 & $\begin{array}{c}0 \\
(.)\end{array}$ & $\begin{array}{c}0 \\
(.)\end{array}$ & $\begin{array}{c}154 \\
(192)\end{array}$ & $\begin{array}{c}0 \\
(.)\end{array}$ & $\begin{array}{c}1700 \\
(.)\end{array}$ & $\begin{array}{c}148 \\
(.)\end{array}$ & $\begin{array}{c}68 \\
(146)\end{array}$ & $\begin{array}{c}228 \\
(372)\end{array}$ \\
\hline 22 & $\begin{array}{c}77 \\
(118)\end{array}$ & $\begin{array}{c}118 \\
(197)\end{array}$ & $\begin{array}{c}138 \\
(175)\end{array}$ & $\begin{array}{c}104 \\
(134)\end{array}$ & $\begin{array}{c}114 \\
(127)\end{array}$ & $\begin{array}{c}113 \\
(144)\end{array}$ & $\begin{array}{c}93 \\
(128)\end{array}$ & $\begin{array}{c}55 \\
(68)\end{array}$ \\
\hline 23 & $\begin{array}{c}63 \\
(121)\end{array}$ & $\begin{array}{c}67 \\
(78)\end{array}$ & $\begin{array}{c}67 \\
(100)\end{array}$ & $\begin{array}{c}97 \\
(117)\end{array}$ & $\begin{array}{c}95 \\
(116)\end{array}$ & $\begin{array}{c}102 \\
(156)\end{array}$ & $\begin{array}{c}89 \\
(159)\end{array}$ & $\begin{array}{c}74 \\
(150)\end{array}$ \\
\hline 24 & $\begin{array}{c}41 \\
(72)\end{array}$ & $\begin{array}{c}45 \\
(78)\end{array}$ & $\begin{array}{c}91 \\
(138)\end{array}$ & $\begin{array}{c}50 \\
(71)\end{array}$ & $\begin{array}{c}59 \\
(66)\end{array}$ & $\begin{array}{c}71 \\
(87)\end{array}$ & $\begin{array}{c}53 \\
(65)\end{array}$ & $\begin{array}{c}49 \\
(58)\end{array}$ \\
\hline 25 & $\begin{array}{c}358 \\
(474)\end{array}$ & $\begin{array}{c}132 \\
(137)\end{array}$ & $\begin{array}{c}123 \\
(154)\end{array}$ & $\begin{array}{c}146 \\
(214)\end{array}$ & $\begin{array}{c}110 \\
(125)\end{array}$ & $\begin{array}{c}153 \\
(145)\end{array}$ & $\begin{array}{c}113 \\
(137)\end{array}$ & $\begin{array}{c}59 \\
(87)\end{array}$ \\
\hline 26 & $\begin{array}{c}103 \\
(123)\end{array}$ & $\begin{array}{c}85 \\
(94)\end{array}$ & $\begin{array}{c}124 \\
(126)\end{array}$ & $\begin{array}{c}129 \\
(117)\end{array}$ & $\begin{array}{c}123 \\
(126)\end{array}$ & $\begin{array}{c}120 \\
(121)\end{array}$ & $\begin{array}{c}111 \\
(144)\end{array}$ & $\begin{array}{c}76 \\
(90)\end{array}$ \\
\hline 27 & $\begin{array}{c}30 \\
(47)\end{array}$ & $\begin{array}{c}8 \\
(6)\end{array}$ & $\begin{array}{c}143 \\
(132)\end{array}$ & $\begin{array}{c}78 \\
(67)\end{array}$ & $\begin{array}{c}126 \\
(179)\end{array}$ & $\begin{array}{c}107 \\
(118)\end{array}$ & $\begin{array}{c}84 \\
(112)\end{array}$ & $\begin{array}{c}77 \\
(138)\end{array}$ \\
\hline 28 & $\begin{array}{c}64 \\
(71)\end{array}$ & $\begin{array}{c}99 \\
(237)\end{array}$ & $\begin{array}{c}93 \\
(163)\end{array}$ & $\begin{array}{c}100 \\
(196)\end{array}$ & $\begin{array}{c}117 \\
(280)\end{array}$ & $\begin{array}{c}100 \\
(187)\end{array}$ & $\begin{array}{c}72 \\
(96)\end{array}$ & $\begin{array}{c}71 \\
(79)\end{array}$ \\
\hline 29 & $\begin{array}{c}39 \\
(58)\end{array}$ & $\begin{array}{l}100 \\
(96)\end{array}$ & $\begin{array}{c}116 \\
(295)\end{array}$ & $\begin{array}{c}98 \\
(128)\end{array}$ & $\begin{array}{c}104 \\
(109)\end{array}$ & $\begin{array}{c}87 \\
(139)\end{array}$ & $\begin{array}{c}73 \\
(75)\end{array}$ & $\begin{array}{c}22 \\
(16)\end{array}$ \\
\hline 30 & $\begin{array}{c}345 \\
(469)\end{array}$ & $\begin{array}{c}153 \\
(271)\end{array}$ & $\begin{array}{c}134 \\
(216)\end{array}$ & $\begin{array}{c}104 \\
(107)\end{array}$ & $\begin{array}{c}107 \\
(160)\end{array}$ & $\begin{array}{c}115 \\
(154)\end{array}$ & $\begin{array}{c}86 \\
(116)\end{array}$ & $\begin{array}{c}80 \\
(95)\end{array}$ \\
\hline 31 & $\begin{array}{c}84 \\
(100)\end{array}$ & $\begin{array}{c}65 \\
(80)\end{array}$ & $\begin{array}{c}85 \\
(97)\end{array}$ & $\begin{array}{c}79 \\
(96)\end{array}$ & $\begin{array}{c}94 \\
(134)\end{array}$ & $\begin{array}{c}89 \\
(123)\end{array}$ & $\begin{array}{c}74 \\
(100)\end{array}$ & $\begin{array}{c}53 \\
(69)\end{array}$ \\
\hline 32 & $\begin{array}{c}232 \\
(452)\end{array}$ & $\begin{array}{c}117 \\
(296)\end{array}$ & $\begin{array}{c}94 \\
(114)\end{array}$ & $\begin{array}{c}79 \\
(105)\end{array}$ & $\begin{array}{c}89 \\
(115)\end{array}$ & $\begin{array}{c}108 \\
(156)\end{array}$ & $\begin{array}{c}88 \\
(112)\end{array}$ & $\begin{array}{c}76 \\
(98)\end{array}$ \\
\hline 33 & $\begin{array}{c}190 \\
(353)\end{array}$ & $\begin{array}{c}211 \\
(414)\end{array}$ & $\begin{array}{c}165 \\
(353)\end{array}$ & $\begin{array}{c}153 \\
(197)\end{array}$ & $\begin{array}{c}136 \\
(210)\end{array}$ & $\begin{array}{c}111 \\
(141)\end{array}$ & $\begin{array}{c}124 \\
(273)\end{array}$ & $\begin{array}{c}71 \\
(73)\end{array}$ \\
\hline 34 & $\begin{array}{c}95 \\
(151)\end{array}$ & $\begin{array}{c}97 \\
(180)\end{array}$ & $\begin{array}{c}119 \\
(164)\end{array}$ & $\begin{array}{c}94 \\
(102)\end{array}$ & $\begin{array}{c}109 \\
(163)\end{array}$ & $\begin{array}{c}106 \\
(127)\end{array}$ & $\begin{array}{c}84 \\
(112)\end{array}$ & $\begin{array}{c}75 \\
(112)\end{array}$ \\
\hline 35 & $\begin{array}{c}104 \\
(220)\end{array}$ & $\begin{array}{c}142 \\
(255)\end{array}$ & $\begin{array}{c}138 \\
(402)\end{array}$ & $\begin{array}{c}113 \\
(149)\end{array}$ & $\begin{array}{c}107 \\
(195)\end{array}$ & $\begin{array}{c}117 \\
(163)\end{array}$ & $\begin{array}{c}86 \\
(139)\end{array}$ & $\begin{array}{c}70 \\
(126)\end{array}$ \\
\hline 36 & $\begin{array}{c}180 \\
(328)\end{array}$ & $\begin{array}{c}159 \\
(214)\end{array}$ & $\begin{array}{c}126 \\
(228)\end{array}$ & $\begin{array}{c}132 \\
(158)\end{array}$ & $\begin{array}{c}114 \\
(242)\end{array}$ & $\begin{array}{c}155 \\
(275)\end{array}$ & $\begin{array}{c}142 \\
(266)\end{array}$ & $\begin{array}{c}66 \\
(100)\end{array}$ \\
\hline 37 & $\begin{array}{c}632 \\
(1662)\end{array}$ & $\begin{array}{c}223 \\
(647)\end{array}$ & $\begin{array}{c}459 \\
(814)\end{array}$ & $\begin{array}{c}378 \\
(916)\end{array}$ & $\begin{array}{c}412 \\
(1433)\end{array}$ & $\begin{array}{c}305 \\
(558)\end{array}$ & $\begin{array}{c}229 \\
(664)\end{array}$ & $\begin{array}{c}111 \\
(134)\end{array}$ \\
\hline 38 & $\begin{array}{c}196 \\
(323)\end{array}$ & $\begin{array}{c}69 \\
(89)\end{array}$ & $\begin{array}{c}151 \\
(279)\end{array}$ & $\begin{array}{c}101 \\
(122)\end{array}$ & $\begin{array}{c}112 \\
(187)\end{array}$ & $\begin{array}{c}131 \\
(339)\end{array}$ & $\begin{array}{c}90 \\
(123)\end{array}$ & $\begin{array}{c}53 \\
(97)\end{array}$ \\
\hline 39 & $\begin{array}{c}245 \\
(872)\end{array}$ & $\begin{array}{c}107 \\
(329)\end{array}$ & $\begin{array}{c}92 \\
(104)\end{array}$ & $\begin{array}{c}60 \\
(90)\end{array}$ & $\begin{array}{c}80 \\
(103)\end{array}$ & $\begin{array}{c}107 \\
(320)\end{array}$ & $\begin{array}{c}70 \\
(105)\end{array}$ & $\begin{array}{c}76 \\
(128)\end{array}$ \\
\hline
\end{tabular}

Notes: This table reports the average estimated number of workers $\left(E S T_{-} W R K R S\right)$ by 2-digit SIC sector and by electoral period. Standard deviations in parentheses. 
TABLE 12. Summary Statistics: EST_WRKRS

\begin{tabular}{ccccccccc}
\hline Div. & Carter & Reagan1 & Reagan2 & BushSr & Clinton1 & Clinton2 & BushJr1 & BushJr2 \\
\hline \hline 1 & 97 & 97 & 120 & 85 & 121 & 107 & 74 & 53 \\
& $(162)$ & $(243)$ & $(364)$ & $(122)$ & $(245)$ & $(186)$ & $(115)$ & $(78)$ \\
2 & 150 & 112 & 85 & 93 & 87 & 77 & 73 & 58 \\
& $(611)$ & $(279)$ & $(185)$ & $(182)$ & $(181)$ & $(153)$ & $(121)$ & $(77)$ \\
3 & 531 & 149 & 175 & 166 & 138 & 142 & 114 & 77 \\
& $(1481)$ & $(310)$ & $(386)$ & $(420)$ & $(247)$ & $(228)$ & $(221)$ & $(113)$ \\
4 & 298 & 141 & 123 & 150 & 139 & 126 & 117 & 72 \\
& $(1108)$ & $(349)$ & $(202)$ & $(394)$ & $(418)$ & $(296)$ & $(288)$ & $(95)$ \\
5 & 189 & 162 & 165 & 173 & 127 & 136 & 107 & 75 \\
& $(619)$ & $(401)$ & $(243)$ & $(226)$ & $(158)$ & $(186)$ & $(152)$ & $(136)$ \\
6 & 259 & 149 & 156 & 168 & 137 & 147 & 112 & 83 \\
& $(585)$ & $(250)$ & $(179)$ & $(180)$ & $(154)$ & $(247)$ & $(133)$ & $(133)$ \\
7 & 143 & 173 & 166 & 162 & 102 & 137 & 140 & 77 \\
& $(527)$ & $(412)$ & $(524)$ & $(562)$ & $(154)$ & $(259)$ & $(268)$ & $(94)$ \\
8 & 26 & 221 & 125 & 137 & 112 & 119 & 91 & 72 \\
& $(87)$ & $(384)$ & $(166)$ & $(267)$ & $(262)$ & $(222)$ & $(160)$ & $(109)$ \\
9 & 119 & 141 & 102 & 83 & 241 & 136 & 138 & 70 \\
& $(542)$ & $(778)$ & $(143)$ & $(137)$ & $(1201)$ & $(279)$ & $(476)$ & $(95)$ \\
\hline \hline
\end{tabular}

Notes: This table reports the average estimated number of workers $\left(E S T \_W R K R S\right)$ by division and by electoral period. Standard deviations in parentheses. 